\title{
EU and OECD to Fight Harmful Tax Competition: Has the Right Path Been Undertaken?*
}

\author{
Carlo Pinto, LL.M., University of Amsterdam
}

\section{Introduction}

This article analyzes some of the issues relating to the current debate on 'harmful' tax competition amongst different countries. Two official documents will be discussed: the European Union (EU) 'Code of Conduct for Business Taxation' (hereinafter: Code of Conduct $)^{1}$ and the Organization for Economic Co-operation and Development (OECD) Report 'Harmful Tax Competition: an Emerging Global Issue' (hereinafter: Report). ${ }^{2}$

The first part deals with a theoretical overview of the general concept of 'tax competition' and the distinction between 'acceptable' versus 'harmful' tax competition as well as the economic implications caused by the latter.

The second part of the article focuses on how the concept of 'harmful' tax competition has been defined in the Code of Conduct and in the Report. Furthermore, it describes the criteria to distinguish acceptable from harmful tax competition as indicated in the two documents.

In the third part, there is a comparison of the content of the Code and the Report, with some comments concerning their common characteristics and differences.

The fourth part presents a survey of certain special tax regimes implemented by EU and OECD Member countries that are potentially 'harmful' tax practices within the meaning of both the Code of Conduct and the Report.
Lastly, the consequences which the Code and the Report envisage with respect to those tax measures considered 'harmful' are discussed. A comparison on this issue as addressed in the two documents follows, with a final comment on the likely developments of the process to tackle harmful tax competition at both $\mathrm{EU}$ and OECD level.

\section{Background to the issue}

\section{A. Concept of tax competition: a 'good' vs. a 'bad' form}

In order to understand the debate currently going on both within the EU and the OECD the first step is to analyze the meaning of the concept of 'tax competition'.

Generally speaking, 'tax competition' is usually referred to as the improvement of a country's national economy as compared to foreign jurisdictions by lowering the internal tax burden in order to increase the competitiveness of domestic business or to attract foreign direct investments. ${ }^{3}$ In particular, the concept of tax competition presupposes that there may be two different goals behind the lowering of the tax burden or, in other words, that there may be a 'good' form as opposed to a 'bad' form of tax competition depending on the underlying result aimed at by the country concerned. ${ }^{4}$

The reduction of the tax burden is acceptable and to

\section{Notes}

* This article is based on the paper '(Harmful) Tax Competition Within the European Union: Concept and Overview of Certain Tax Regimes in Selected Member States', written on the occasion of the LOF Conference on 'Tax Competition within the European Union' held in Amsterdam on 25 September 1998 and published in the book of this conference as well as in the World Wide Web site of LOF at: < www.lof.nl >.

The author wishes to thank Prof. Peter J. Wattel (University of Amsterdam) for his invaluable comments, and Prof. Richard T. Ainsworth (Harvard Law School) for his precious suggestions.

1 The Code of Conduct was approved by the ECOFIN Council Meeting on 1 December 1997 and published in the OJ No. C2 of 6 January 1998 , p. 1.

2 The OECD Report was approved by the OECD Council on 9 April 1998 and released on 28 April 1998.

3 For the definition of the general concept of tax competition and its economic implications outlined in this article, the following bibliography has been consulted: D. Kenyon \& J. Kincaid, Competition amongst States and Local Governments, (Washington DC); Sinn, Hans \& Werner, 'Tax Harmonisation and Tax Competition in Europe', no. 34, p. 489; Shannon, 'Tax Incentives and Tax Sparing', in Intertax 1992/2, p. 84; A. Easson, 'Fiscal Degradation and the Inter-nation Allocation of Tax Jurisdiction', EC Tax Review 1996/3, p. 112; de Kam, de Haan et al., 'Who Pays the Taxes? The Distribution of Effective Tax Burdens in Europe', EC Tax Tax Jurisdiction', EC Tax Review 1996/3, p. 112; de Kam, de Haan et al., 'Who Pays the Taxes? The Distribution of Effective Tax Burdens in Europe', EC Tax
Review 1996/4, p. 175; A. Easson, 'Tax Competition and Investment Incentives', EC Tax Journal 1996-97/2, p. 63; J. Owens, 'Emerging Issues in Tax Reform: The Perspective of an International Bureaucrat', Tax Notes International, 22 December 1997, p. 2035; D. Kenyon, 'Theories of Inter-jurisdictional Competition', New England Economic Review, 1997/3-4, p. 13.

4 The tax burden referred to in the text concerns exclusively direct taxation as a whole, including e.g. administrative and compliance costs imposed on taxpayers. Therefore, indirect taxes are outside the scope of the two documents under review, the main reason being that they do not play a fundamental role in some OECD countries (i.e. in the USA) and that they are harmonized within the European Union (see Arts. 95 through 99 of the EC Treaty). 
be welcomed if it is directed towards an increase in the competitiveness of domestic business through a decrease of the direct taxes levied on profits derived therefrom. 'Good' tax competition forces governments to maintain reasonably low levels of public expenditure and to find an appropriate balance between the total tax burden imposed on taxpayers and an acceptable level of public services and social infrastructures.

More specifically, this form of tax competition is driven by internal policy goals and decisions meant to achieve greater fairness and neutrality in the countries' tax systems. Thus, such policies are likely to lead to desirable changes in their overall tax structure, such as the broadening of the taxable base and lowering of tax rates.

The situation changes where a country's goal behind the decrease of the tax burden is exclusively or primarily to attract foreign direct investments: this may bring about 'bad' or 'harmful' tax competition. From a practical point of view, this goal may be achieved by way of several different mechanisms operating through the direct tax system. For instance, a certain country may grant a reduction of the corporate tax rate applicable on income earned by foreign investors, a tax holiday for a limited or an unlimited period in favour of foreign investors, a reduction of withholding tax rates on outbound income distributions, special investment allowances, formation of tax-free reserves, accelerated depreciation deductions for foreign investors, or the creation of special tax-free zones.

These are examples of what in practice may be considered 'harmful' tax competition. However, the theoretical concept deserves further analysis. In particular, the questions arising at this stage are: what is really meant by 'harmful' tax competition? And what is (are) the criterion (criteria) to distinguish between 'acceptable' and 'harmful' tax competition?

\section{B. 'Harmful' tax competition and its adverse economic consequences}

The EU Code of Conduct and the OECD Report do not contain a clear and unambiguous answer to the questions asked, due to the absence in them of a clarification of the theoretical concept of tax competition and of the borderline between 'acceptable' and 'harmful'. However, this lacuna present in the two documents is filled by way of a reference to the adverse economic consequences caused by the implementation of certain potentially harmful tax measures.

The most dangerous economic implication of harmful tax competition is indicated to be the socalled 'fiscal degradation', i.e. the loss of revenue borne by the countries engaged in the lowering of their taxes on income derived from capital investments and, ultimately, the erosion of their taxable base. Such countries are bidding against each other in minimizing the tax burden on foreign investors' income in order to attract their capital and business activities. This situation implies dangerous beggar-thy-neighbour policies. The result of this race to the bottom is that the countries to which investments shift due to the implementation of favourable tax regimes gain insignificant tax revenue, whereas the countries from which investments shy away lose large amounts of tax revenue, with everyone winding up poorer (except some internationally mobile taxpayers).

The negative consequences caused by fiscal degradation and beggar-thy-neighbour policies are several. First, the lack of tax revenue entails a decrease in the resources available to governments to fund their public spending. This, in turn, leads either to a decrease in the quality of public services and ultimately in a country's welfare system, or to the need to seek alternative sources of revenue.

In the latter case, undesirable distortions are brought about especially by an increase in the taxation on labour (i.e. on wage earners), due to the potential impact on unemployment and to the replacement of labour with capital in the production process. Furthermore, there may be tax equity concerns. In particular, both vertical and horizontal equity are likely to be negatively affected in that the tax burden is in proportion much higher on wage earners than on rich taxpayers and, from an international point of view, that domestic taxpayers are more heavily taxed than foreign taxpayers.

Even more significant are the economic inefficiencies acknowledged to be caused by 'harmful' tax competition. In this regard, a misallocation of the resources occurs with respect to investment decisions purely driven by tax considerations. Put in another way, if an investment in a certain country would not have been made in the absence of a tax incentive implemented by it, this means that the resources are not in the best possible location and are not used in the most efficient way from an economic point of view.

'Bad' tax competition also entails drawbacks from a political and democratic point of view. In fact, national jurisdictions outbidding each other surrender themselves to the market, although they are convinced that they are retaining their fiscal sovereignty. In other words, their tax policies are dictated by taxpayers rather than by the goal of imposing a reasonable part of the cost of public expenditure on every production factor, including the mobile capital one.

It is common ground amongst representatives of the countries belonging to the EU and the OECD as well as eminent economists that harmful tax practices must be countered so as to reduce the aforementioned economic distortions. However, the problem arises as to how to identify in practice the different tax measures implemented by the various governments to be considered as 'harmful'. For this purpose, several indicators have been laid down in both the EU Code of Conduct and the OECD Report that are deemed to show clearly the 'harmful' character of a certain tax measure. 


\section{EU Code of Conduct and OECD Report: legal nature, scope and criteria to identify harmful tax practices}

\section{A. The EU Code of Conduct ...}

One of the hottest tax issues currently under the attention of the European Union institutions is the implementation by a number of Member States of tax regimes potentially harmful for the correct functioning of the internal market.

As the four freedoms contained in the EC Treaty have made it possible for people, goods, services and capital to circulate freely within the EU, the integration of the European market has become a reality and cross-border trade and investments have assumed an ever-increasing importance over the last decade. In this picture, direct taxation plays a significant role.

This will be especially true after the successful implementation of the Economic and Monetary Union (EMU), which will shortly lead to the disappearance of the potential distortions to the functioning of the internal market stemming from different exchange and interest rates in the Member States, namely the lack of price transparency and 'proțectionist' measures. In particular, exchange rates will no longer exist upon the introduction of the euro, and interest rates will converge and ultimately be set by the European Central Bank. ${ }^{5}$ Consequently, policy competition through exchange and interest rates will become impossible, and the importance of the direct tax regimes implemented by the EU countries in affecting investment decisions will rise significantly, causing a sharp increase of tax competition.

The process meant to counter harmful tax competition within the EU culminated in the adoption of the Code of Conduct. The latter is part of a more comprehensive 'Package to Tackle Harmful Tax Competition in the European Union' (hereinafter: Package), approved by the ECOFIN Council on 1 December 1997.6 The adoption of these documents started upon the initiative of the European Commission at the informal ECOFIN Council held in Verona in September 1996, and continued with the subsequent proposals submitted by the former to the Council. ${ }^{7}$

The general goal aimed at is indicated as the need to tackle harmful tax competition within the EU in order to reduce and ultimately eliminate the economic distortions, the fiscal degradation and the increase of taxation on labour created by it, which leads to a growth of the already high unemployment rate. ${ }^{8}$ The key instrument is the Code of Conduct, which explicitly targets all tax measures implemented by the Member States that harm the Community interest.

No less important, however, are the other elements contained in the Package. ${ }^{9}$ First of all, there is the acknowledgement of the need to implement a directive meant to ensure a minimum level of taxation on interest income received by residents of a Member State in a country other than that of their residence. As a consequence, a Proposed Directive on the taxation of interest from savings has been submitted by the Commission to the Council. ${ }^{10}$ It features the imposition of a minimum withholding tax to be levied on interest payments effected to non-resident EU citizens by the EU country in which such payments are made or, alternatively, an exchange of information with the recipient's EU country of residence (so-called coexistence model). The final adoption of this directive would ensure a minimum level of taxation on income from savings, for which most (EU) countries are currently tempted to grant favourable tax regimes because of its easy mobility.

In addition, the Package calls for the abolishment of the imposition of withholding taxes on intra-group payments of interest and royalties, so as to avoid distortions caused by international economic double taxation on them. Pursuant to this commitment of the Member States, the Commission has released a Proposed Directive on intercompany payments of interest and royalties, ${ }^{11}$ which covers these kinds of payments made between associated companies and relies on the principle of taxation in the residence country of the recipient company.

Last but not least, the Package indicates that the Commission must submit a set of guidelines containing specific conditions and rules for the subject area of state aid in direct taxation matters (see below). This would solve the problems relating to the legal uncertainties arising in the application of the general state-aid rules to direct taxation.

The main document of the Package to be relied on in the tackling of harmful tax competition is the Code of Conduct for Business Taxation. It is important first to analyze its legal nature. The Code has been adopted

\section{Notes}

5 For a comment on the implications of the introduction of the euro on direct tax matters, see among the others: P. Harrison, 'Tax Implications of the Introduction of the Euro', Intertax 1998/3, p. 93; O. Ruding, 'After the Euro: Corporation Tax Harmonization?', EC Tax Review 1998/2, p. 72; F. Vanistendael, 'Redistribution of Tax Law-Making Power in EMU?', EC Tax Review 1998/2, p. 74; L. Stevens, W. van der Beek \& R. A. Sommerhalder, 'The Euro: Taxation Policy and Practical Tax Implications', EC Tax Review 1998/2, p. 95.

6 The Package was published in the OJ No. C2 of 6 January 1998, p. 1. Information on the latest developments on this subject as well as on the European Union institutions and policies may be found on the EU World Wide Web site: < europa.eu.int >.

7 The proposals were contained in the documents COM (97) 495 final of 1 October 1997, and COM (97) 564 final of 5 November 1997.

8 See the Council Conclusions on Taxation Policy contained in the Package and the preamble of the Code of Conduct.

9 For a comment on the Package, see H. M. Liebman \& S. Leventhall, 'Moving Towards Tax Co-ordination', European Taxation 1998/3, p. 96.

10 Commission DOC (295) final of 20 May 1998.

11 Commission DOC (67) final of 4 March 1998. 
by the Council as a resolution, a non-legally binding instrument. In effect, the Code merely constitutes a political commitment of the Member States to comply with what is agreed upon therein and its provision may not be enforced through legal remedies by the EU institutions or by the Member States in case of failure to adhere to its provisions.

As to the scope, the Code applies to those tax measures dealing with business taxation "which affect, or may affect, in a significant way the location of the business activity in the Community'. ${ }^{12}$ Tax measures, in turn, are defined as encompassing not only laws, but also regulations and administrative practices: ${ }^{13}$ in principle all the (special) tax regimes implemented by the Member States fall under its rules regardless of their legal form.

Therefore, it may be implied that the definition of 'harmful' endorsed by the Code refers to those measures which play a fundamental role on the companies' decisions on their investment location. Accordingly, a certain tax measure implemented by a Member State is considered harmful for the Community interest where the decision of a taxpayer on the country in which his business activity should be located has been affected exclusively or preponderantly by such a tax measure.

In order to specify this rather vague and open-ended definition and to provide a practical tool to make it workable, the Code contains several indicators that help to single out what measures constitute 'harmful' tax competition. In particular, the Code points to measures that provide for a total (i.e. zero rate) or a significant reduction in the effective tax burden imposed on business taxation. ${ }^{14}$ All tax provisions leading to this result are covered, regardless of whether they have effect in respect of the nominal tax rates, of the tax base, or of other factors, ${ }^{15}$ such as depreciation schedules, tax treatment of reserves and provisions, and the like.

Turning to the markers that are indicated actually to show the 'harmful' character of specific tax measures implemented by Member States, the Code mentions: ${ }^{16}$

- deviation of a fiscal measure from the 'benchmark' tax system of the country concerned, e.g. availability of a tax incentive only to non-resident taxpayers or to transactions concluded with nonresident taxpayers; ${ }^{17}$

- no repercussions of a tax incentive on the domestic tax base of the country concerned due to the fact that they are completely unlinked to the domestic economy (i.e. ring-fencing);

- availability of a tax incentive to investors regardless of their having actual economic presence or carrying on a real economic activity in the country concerned;

- availability of a tax incentive entailing the computation of taxable income according to principles other than the internationally accepted ones (especially the OECD transfer-pricing rules) in favour of multinational companies;

- lack of transparency of a tax incentive, because for instance it is granted according to an unpublished administrative practice departing from general statutory principles in effect in the country concerned.

Finally, in addition to the above indicators the Code contains other factors that need to be taken into account in the assessment on the 'harmful' nature of a certain tax measure implemented by a Member State: ${ }^{18}$

- the so-called spillover effect, i.e. the actual impact that it provokes with respect to other (neighbouring) Member States' economies, with a comparison of the latter's tax treatment of the same or similar taxpayers or activities;

- the underlying policy pursued by that Member State with its introduction, and, in particular, whether it was meant to favour the economic development of depressed or underdeveloped areas within the EU such as 'outermost regions and small islands'. ${ }^{19}$

\section{Notes}

12 Code of Conduct, Para. A (1).

13 Ibid., Para. A (3)

14 Ibid., Para. B (1)

15 Ibid., Para. B (2)

16 Ibid., Para. B (3), Nos. (1)-(5).

17 This test is very important for this purpose and is not a new one in the practice of EU law. In fact, it is also used by both the Commission and the European Court of Justice in the assessment of the compatibility of fiscal state aid measures with EC law (see e.g. the Annual Reports on Competition Policy published by the European Commission). The EC rules on state aid are contained in Arts. 92 and 93 of the EC Treaty and set out a general prohibition for the Member States to grant aids to undertakings in any forms, including by way of their direct tax system. However, there are limited exceptions explicitly listed in Art. 92 under which it is possible to enact state aid measures provided certain conditions are met. By oversimplifying it, amongst the listed exceptions there is an allowed form of 'regional state aid', which may consist of fiscal incentives limited to a certain territory and/or to certain categories of taxpayers (namely foreign investors) in cases of serious underdevelopment or underemployment in that area. Hence, it may be implied that as a general rule these forms of fiscal state aid measures only available to foreign investors are in principle incompatible with EU law because they are in breach of the general prohibition laid down in Art. 92.

18 Code of Conduct, Para. G. These criteria are indicated as additional practical tools to be used in the assessment of harmful tax measures and are contained in the section of the Code dealing with the review process (see below).

19 This provision is meant to provide a 'safety valve' for those tax measures characterized as fiscal state aid in case of overlap of the different sources of EU law. 


\section{B. ... and the OECD Report}

The issue of harmful tax competition has been recently dealt with also by the OECD Report. ${ }^{20}$ It was the outcome of a project meant to 'develop measures to counter the distorting effects of harmful tax competition on investment and financing decisions and the consequences for national tax bases', which was delegated by the Member countries' ministers to the organization in May 1996.

The Report contains an introduction and three chapters concerning the concept of tax competition, the criteria to identify harmful tax competition, and the recommendations to counter harmful tax competition. ${ }^{21}$ In this Section, the first two chapters will be described.

As to the scope of the Report, the introduction points out that it only covers 'geographically mobile activities, such as financial and other service activities, including the provision of intangibles'. ${ }^{22}$ Therefore, special tax measures enacted with a view to favouring manufacturing activities do not fall under the scope of the Report, nor do measures relating to indirect taxation.

The first chapter contains the economic background of tax competition and an analysis of this concept. In particular, it is highlighted that the globalization of economy and investments has made it possible to shift capital and business activities much more easily than in the past, thereby making domestic fiscal policies of the various countries potentially more able to affect other countries' economies and markets. This has been the main factor causing an increase of tax competition.

With regard to the concept of tax competition, the Report describes its two different forms. Good or 'acceptable' tax competition is said to stem from the differences in the tax systems of the various countries due to their different internal fiscal policies. ${ }^{23}$ Furthermore, it is acknowledged that good tax competition encompasses all those tax measures implemented by the countries in the pursuance of internationally accepted standards, given their full sovereignty in the area of direct taxation. Consequently, tax incentives are to be considered as 'acceptable' where they are adopted as a tool of domestic policy to attract new and genuine investments or to favour the development of depressed areas suffering from specific disadvantages, such as unemployment, lack of natural resources and the like.

When turning to the concept of 'harmful' tax competition, the OECD Report becomes indeed rather confusing for the lack of a concise definition of what is 'harmful' as opposed to 'acceptable'. Thus, its definition must be construed by putting together its pieces scattered throughout the Report. Doing so, it appears that 'harmful' tax competition is to be understood as a country's exploitation of the interaction of the tax systems 'by the enactment of special tax provisions which principally erode the tax base of other countries'. ${ }^{24}$

Furthermore, a synonym for harmful tax competition seems to be the term 'poaching'. This is explained to mean that 'the spillover effect on the other countries is not a mere side effect, incidental to the implementation of a domestic tax policy', but 'the effect for one country to redirect capital and financial flows and the corresponding revenue from the other jurisdictions by bidding aggressively for the tax base of other countries'. ${ }^{25}$

The following forms of potential harm are indicated as likely to be caused by the implementation of special tax incentives falling in this category:26 distortion of investment flows; threat to the integrity and fairness of the tax systems; discouragement of taxpayers' compliance; redesign of the appropriate balance between revenue and public spending; shift of tax burden to other bases, namely labour and consumption; increase of administrative and compliance costs. ${ }^{27}$

Chapter 2 of the OECD Report contains the criteria to identify harmful tax practices within the described meaning. A distinction is made between 'tax havens' and 'harmful preferential tax regimes' adopted by countries not considered tax havens (notably, OECD Member countries), which together constitute 'harmful tax practices' covered by the Report. ${ }^{28}$

\section{Notes}

20 For useful information on the structure and functions of the OECD as well as a current update on its activities in tax matters, visit the organization's World Wide Web site at: < www.oecd.org > . For an overview of the OECD Report, see J. Owens, 'Curbing Harmful Tax Competition - Recommendations by the Committee on Fiscal Affairs', Intertax 1998/8-9, p. 230.

21 For an interesting comment on the OECD Report, see A. W. Wright, 'Review: OECD Harmful Tax Competition Report Falls Short', Tax Notes International, 17 August 1998, p. 461 and the replies by E. Osterweil, 'In defence of the OECD Report on Harmful Tax Competition', Tax Notes International, 21 September 1998, p. 895 and J. Francke, 'The 1998 OECD Report on Harmful Tax Competition: Just right', Tax Notes International, 28 September 1998, p. 979.

22 OECD Report, p. 8.

23 Ibid., p. 15 .

24 Ibid., p. 16.

25 Ibid.

26 Ibid.

27 See on the point Wright, at n. 21 above, p. 462. In particular, with respect to the definition of 'harmful' tax competition the author refers to the introduction of the OECD Report (p. 8), which reads: 'the Report is intended to develop a better understanding of how ... harmful tax practices affect the location of financial and other service activities, erode the tax bases of other countries, distort trade and investment patrerns and undermine the fairness, neutrality and broad social acceptance of tax systems generally.' Furthermore, the author cites the following part of the Report (p. 14): (harmful tax practices) 'induce potential distortions in the patterns of trade and investment and reduce global welfare ... may alter the structure of taxation (by shifting part of the tax burden from mobile to relatively immobile factors and from income to consumption) and may hamper the application of progressive tax rates and the achievement of redistributive goals.'

28 OECD Report, p. 8 (introduction) and pp. 19 et seq. (Chapter 2). 
The concept of tax haven is not defined in the Report because it 'does not have a precise technical meaning'. ${ }^{29}$ However, it is pointed out that it refers to countries 'that are able to finance their public services with no or only nominal income taxes and that offer themselves as places to be used by non-residents to escape tax in their country of residence (so-called reputation criterion)'; furthermore, they 'raise significant revenues from their income tax but whose tax system has features constituting harmful tax competition'. ${ }^{30}$ Therefore, tax havens are perceived as being actively engaged in the erosion of the other countries' taxable base and as being unwilling to be involved in the process meant to combat harmful tax practices.

The second category constituting 'harmful tax practices' is made up of countries that collect a significant level of revenue from individual and/or corporate income tax but whose tax systems 'have preferential features that allow the relevant income to be subject to low or no taxation'. ${ }^{31}$ The tax revenues of such countries are jeopardized by the existence of both tax havens and preferential regimes enacted by other competing countries. Consequently, they are perceived as being more inclined to cooperate in the fight against harmful tax practices as long as their competitors agree to do the same.

In order to identify 'harmful' tax practices under the scope of the Report, several indicators relating to tax havens and/or preferential tax regimes implemented in non-tax-haven jurisdictions are laid down:32

- no or only nominal taxes, as well as a low effective tax rate on the relevant income (i.e. from mobile activities) due to a low nominal rate or to a narrow definition of the tax base or to a combination;

- 'ring-fencing' of a certain tax regime, that is insulation from the rest of the economy due to its unavailability to resident taxpayers or to its availability exclusively to non-resident taxpayers;

- lack of taxpayer's real or substantial business activities required to benefit from a favourable regime, which gives rise to so-called 'booking centres;'

- lack of effective exchange of information in a country's legislation, namely banking secrecy legislation and administrative practices preventing supply of relevant information on taxpayers' activities and funds;

- lack of transparency of certain tax regimes due to favourable administrative practices of a country's tax authorities, which: (a) issue favourable rulings without publishing the required (objective) conditions; (b) grant them on a discriminatory basis or non-consistently with statutory laws; or (c) fail to enforce statutory tax provisions (i.e. adopt a lax audit policy);

- artificial definition of the tax base, including: (a) provisions narrowing the tax base; (b) unconditional rules for the avoidance of double taxation, such as full credit and unrestricted participation exemption; (c) deductions for deemed expenses; (d) rules allowing the formation of special reserves and provisions; (e) computation of the taxable base on the basis of the cost-plus or resale-minus method or of other non-transparent notional methods;

- failure to comply with internationally accepted transfer-pricing rules, such as: (a) calculation of adjustments on narrow bases; (b) inappropriate use of advance rulings in this area; (c) use of 'safeharbour' prices or margins;

- adoption by a country of the full exemption method for relieving double taxation on foreignsource income.

In addition, there are other criteria explicitly set out in the Report, but they seem to be superfluous because they are already implied by the aforementioned. ${ }^{33}$ Finally, the practical judgment on the 'harmful' character of a certain tax measure must consider the following economic effects caused by its implementation: ${ }^{34}$

- mere relocation by taxpayers of an already existing investment with a view to taking advantage of the preferential regime rather than the generation of new investments;

- creation of new activities commensurate with the size of the investment or the income obtained;

- lack of motivations for an investment other than the exploitation of the favourable tax measure.

\section{Comparative analysis of EU Code of Conduct and OECD Report}

\section{A. Scope and criteria to identify 'harmful' tax competition}

It is now possible to make further comments on the EU Code of Conduct and the OECD Report and compare their scope and content. The relationship and the

\section{Notes}

29 OECD Report, p. 20. On this point, see also Wright, at n. 21 above, p. 462, and M. Dionne, 'Tax Havens - An Introduction', Tax Notes International, 17 August 1998, p. 430.

30 OECD Report, p. 20.

31 Ibid., p. 19.

32 OECD Report, pp. 21 et seq. Actually, the Report breaks down the relevant criteria in two distinct categories with respect to tax havens and to preferential tax regimes of non-haven jurisdictions, but they coincide and therefore are mentioned only once in the text for the sake of simplicity.

33 OECD Report, pp. 32 et seq. In particular, the following ones are mentioned: (a) possibility for a taxpayer to negotiate the tax rate or tax base with the tax authorities of the country concerned; (b) existence in the country of secrecy legislation, including banking secrecy, anonymous debt instruments or bearer shares; (c) existence of regimes favouring purely tax-driven transactions and involving no substantial activity.

34 OECD Report, pp. 34-35. 
differences between the two documents are well summarized in the OECD Report, which stresses their broad compatibility as well as their mutual reinforcing character and at the same time the divergent scope and operation. ${ }^{35}$

The scope of the Code of Conduct is wider than that of the Report because it covers business taxation as a whole and not merely taxation on income from mobile activities. On the other hand, the scope of the OECD Report is geographically more extended, because the number of countries forming part of the organization is bigger than that of EU countries.

Nevertheless, the scope of both documents is far from comprehensive. In fact, indirect taxation is completely out of their coverage even though it may be that a certain VAT or consumption tax incentive (i.e. zero or reduced rates) does have harmful effects where it is directed towards attracting foreign companies. Within the EU, this is explained due to the harmonization of indirect taxes as a matter of principle. However, as there still are differences especially in the VAT provisions implemented by certain Member States, the concept of tax competition may also refer to indirect taxation. ${ }^{36}$

In addition, direct taxation on individuals is left outside the reach of both Code and Report. In this area, there are certain 'expatriate' regimes that might indeed be considered 'harmful' tax competition. The latter consist of granting a full or partial exemption from income taxation in respect of compensation or fringe benefits paid to executives or highly skilled personnel. Their underlying goal is usually to make it attractive for multinational groups of companies to assign them to job positions available in the country granting these special regimes. ${ }^{37}$

As to the criteria indicated in the Code and the Report to identify 'harmful' tax practices, several are common, whereas there are some slight differences between them (see the table).

The indicator under i) in the table is mentioned in both documents but in a different context. The Code of Conduct points out that amongst the measures covered as potentially harmful are those providing for an effective tax burden significantly lower that that applicable under the standard system of a certain country, including zero taxation. ${ }^{38}$ This criterion is thus closely related to the one under ii) in the table.

On the other hand, the OECD Report explicitly mentions indicator i) in the definition of 'tax haven'

\begin{tabular}{|c|c|c|c|}
\hline \multicolumn{2}{|c|}{$\begin{array}{l}\text { Criterion to identify harmful tax } \\
\text { practices }\end{array}$} & \multirow{2}{*}{$\begin{array}{l}\text { EU } \\
\text { Code of } \\
\text { Conduct } \\
0\end{array}$} & \multirow{2}{*}{$\begin{array}{l}\text { OECD } \\
\text { Report } \\
X\end{array}$} \\
\hline i) & No or only nominal taxes & & \\
\hline ii) & $\begin{array}{l}\text { Deviation of a tax measure from the } \\
\text { 'benchmark' tax system }\end{array}$ & $x$ & $x$ \\
\hline iii) & Ring-fencing from the domestic economy & $x$ & $x$ \\
\hline iv) & No substantial economic presence & $x$ & $x$ \\
\hline v) & $\begin{array}{l}\text { Computation of taxable income } \\
\text { according to principles other than } \\
\text { internationally accepted ones }\end{array}$ & $x$ & $x$ \\
\hline vi) & $\begin{array}{l}\text { Lack of transparency (administrative } \\
\text { practices) }\end{array}$ & $x$ & $x$ \\
\hline vii) & $\begin{array}{l}\text { Lack of effective exchange of } \\
\text { information (banking secrecy legislation) }\end{array}$ & - & $x$ \\
\hline viii) & Other economic indicators & 0 & $x$ \\
\hline
\end{tabular}

and makes it the chief indicator to label a country as such, the other being the subjective and rather vague 'reputation' test.

The test indicated under ii) in the table is present in both the EU Code and the OECD Report. It implies that the reduction of the tax burden in a country is to be granted by way of 'special' incentives limited to a certain category of taxpayers (i.e. non-resident ones) or of transactions (i.e. those concluded with nonresidents). This in turn highlights that the most important factor in the assessment of a certain measure as 'harmful' is its speciality as compared to the standard tax system applying to resident taxpayers in the same country. In other words, harmful measures are those which deviate from the 'benchmark' tax system in effect in a certain country and are targeted exclusively towards the attraction of foreign investments with a goal to redirect them from other countries, thereby eroding their tax base.

The reverse side of this test is that tax measures forming part of a country's benchmark tax system do not constitute harmful tax competition. However, in this regard several fiscal theorists maintain that tax measures implemented generally through the standard tax system may nevertheless be harmful, such as a very low rate of corporate taxation, the absence of withholding taxes on outbound income distributions, favourable depreciation provisions and the like. ${ }^{39}$

\section{Notes}

35 See the introduction to the OECD Report, p. 11.

36 This has also been acknowledged by the EU Commission, which in its first proposal on the adoption of the Code singled out specific VAT rules that would fall within its scope, namely in the areas of investment gold, passenger transport and energy products: see COM (97) 495 final, p. 9. In its final version, however, the scope of the Code has been limited to direct taxation, because Member States could not reach an overall consensus on this matter.

37 It is worth noting that the European Commission did include special expatriate regimes amongst potentially harmful measures in its first proposal to the adoption of the Code of Conduct (see COM (97) 495 final). However, they were left out of the final version of the Code because some Member States felt that these measures were protected by their national sovereignty in direct tax matters and a unanimous consensus was not reached in this area.

38 Code of Conduct, Par. B (1).

39 With respect to this point, see in particular Easson, at n. 3 above, p. 77. 
For instance, the new corporate tax system planned to be implemented in Ireland relies on a general tax rate of 12.5 per cent on trading income as from 1 January 2003. According to the criterion under review, it is not to be labelled as 'harmful' because it covers all trading income derived by both resident and nonresident taxpayers and is therefore not 'special'. However, its potential economic consequences may be comparable to those caused by truly 'special' measures. ${ }^{40}$

Another example is the exemption from withholding tax on outbound payments, which, although a general provision included in certain countries' tax systems, is likely to favour (almost) exclusively foreign investors: it is not considered 'harmful' according to the above test because it is not special.

A final example of a general measure, 'normal' in a country, but nonetheless potentially harmful, is banking secrecy, which has been pointed at exclusively by the OECD Report. The conclusion is thus that also general measures should be scrutinized, because they may turn out to be harmful tax competition on the same footing as the special ones.

The criterion under iii) in the table, ring-fencing, is interpreted as a fiscal incentive being insulated from the domestic economy so as not to have repercussions on the tax base of the country granting it. Indeed, this statement is not quite consistent, because every tax incentive has by definition an impact on the domestic base of the country concerned.

Let's assume hypothetically that the tax incentive granted by that country consists of a total exemption from corporate income tax on mobile activities of nonresident companies and that all of their income enjoys such exemption: there is still an impact on that country's tax base. In fact, it is likely that the employees of those non-resident companies are taxed, as is income induced by their investments not covered by the scope of the exemption. Furthermore, assuming that part of the investments would have been made by some non-resident companies even in the absence of such incentive, that country's tax base would still be affected, due to the fact that it would collect a higher level of tax revenue by fully taxing income generated by these investments.

It is worth noting that this criterion is interpreted by the OECD Report as having the same meaning as the one analyzed under ii), because it is explained to apply where the incentive is not available to resident taxpayers of the country concerned or is restricted to its non-resident taxpayers. The same remarks made above with respect to this restriction hold true also in this situation.

The indicator under iv) in the table is a very useful tool in identifying harmful tax practices. In particular, the test of availability of a tax incentive regardless of a substantial presence of its beneficiary in the country granting it clearly shows that, on the one hand, a company has invested in that country only because of the incentive, and on the other hand that the country is only trying to attract (mobile) business activities rather than pursue a sound domestic fiscal policy.

The criterion under $\mathrm{v}$ ) in the table is meant to cover all the special regimes relying on the computation of taxable profits in a way other than the standard one based on a company's financial statements, by unnecessarily resorting to notional methods like the 'cost-plus' one. This is a very relevant test showing the potentially harmful character of a tax measure, especially due to its 'deviation' from the benchmark tax system of that country.

It is to be noted that the OECD Report goes further by making clear that also certain administrative practices relating to transfer pricing need to be labelled as harmful. This is especially the case of the so-called 'safe-harbour' rulings, under which a country's tax authorities commit themselves not to undertake a transfer-pricing procedure as long as the profits of a certain (non-resident) entity are at least equal to a certain amount calculated under mechanisms such as the 'cost-plus' or the 'resale-minus'.

The test under vi) is also very important because it targets all of the 'hidden' incentives aimed at attracting foreign direct investments. A favourable administrative practice granting a favourable tax treatment is an example of what may fall under this category. They are probably the most dangerous forms of harmful tax competition, because they are difficult to detect and rely on a high degree of discretion exercised by a country's tax administration. Therefore, they may give rise to inequalities of tax treatments between taxpayers aware or unaware of their existence, as well as 'manipulations' of the general tax system by the tax administration in a manner escaping judicial, administrative, and ultimately democratic control.

The most relevant difference between the Code of Conduct and the Report is the criterion indicated in the table under vii), which is absent in the Code. According to it, where a country has banking secrecy legislation it ought to be considered a 'tax haven' because of the adverse consequences brought about by this kind of legislation, namely the creation of another obstacle to the fight against tax evasion and money laundering. ${ }^{41}$

It is apparent that these observations hold true even though it is probably not totally true that all of the countries which have secrecy laws are to be considered tax havens. This is also shown by the fact that Luxembourg and Switzerland, although having enforced banking secrecy rules stricter than those of

\section{Notes}

40 It is interesting to note that the EU Commission has agreed on the introduction by Ireland of the reduced 12.5 per cent rate on trading income on 22 July 1998 . See M. Walsh, 'Ireland, EU Agree to Major Changes in Irish Tax Regime', Tax Notes International, 3 August 1998, p. 282.

41 See the OECD Report, pp. 24 and 30. 
all of the other OECD countries, nevertheless impose a considerable tax burden on their taxpayers. It is true that they have favourable regimes in respect of certain categories of (mobile) income. However, it makes a difference being considered a high-tax jurisdiction with certain harmful tax measures or as a tax haven altogether. This is probably the main reason why these two countries have not endorsed the OECD Report, which is consequently 'mutilated' and lacks full (political) coerciveness due to these countries' positions. $^{42}$

\section{B. No definition of 'harmful' tax competition}

From the analysis of both the Code of Conduct and the OECD Report it is crystal clear that there exists no general, comprehensive and universally accepted definition of 'harmful' tax competition.

The reasons for this are several. First, the issue is relatively new because it is interwoven with the globalization of the economy and the abolition of the restrictions to the circulation of capital, which have been occurring only in the last few years. Secondly, there has been (and there still is) uncertainty as to the economic consequences of the various tax measures due to the lack of data on the international spillover effects brought about by them, as also acknowledged by the OECD Report. ${ }^{43}$ Thirdly, up to a few years ago there was reluctance to deal with the issue of harmful tax competition openly and even to acknowledge its existence as well as the need for coordinated action to tackle it, due to the belief that the best way to cope with it was actively to engage in it.

The Code of Conduct refers to the potential impact and relevance of a certain tax measure in affecting undertakings' decisions on the location of their investment. In other words, the Code highlights that a tax measure is to be defined as 'harmful' where it has such an impact on the investment location decision of a certain company that the other social, legal and economic factors usually considered are becoming of secondary importance.

This approach lacks legal certainty because it involves a subjective investigation into the intentions and motivation of a certain taxpayer in his decision on where to locate his investment. Furthermore, it does not distinguish between new investments and the mere relocation of already existing investments shifted to another country only because of a favourable tax measure.

These considerations are implicitly confirmed by the OECD Report, which does not encompass this indicator amongst the main ones showing the harmful character of a certain tax measure. Instead, the Report mentions it among the economic criteria to be used for this purpose, and more specifically requires to test the potential impact of a tax measure: (a) on the investment location decision; and (b) on the nature of the investment made in pursuance of that tax measure, i.e. whether it is a mere relocation of an already existing investment or a new investment generated by it.

However, with respect to criterion under (a) the Report recognizes that 'in practice it is not always easy for the tax authorities to evaluate the motivation of investors and that non-tax factors ... may also influence location decisions'. ${ }^{44}$ As to the one under (b), it acknowledges that 'determining whether investment represents a new investment or a shift from another location to exploit tax differentials is a difficult empirical matter'. ${ }^{45}$

Consequently, the main problem linked to the definition of harmful tax competition given in the Code of Conduct is that the investment location decision depends on a number of different factors that are difficult to be singled out and assessed in practice. In fact, most theorists point out that usually investment decisions are affected by several considerations amongst which taxation does not bear any particular relevance as compared to the others, all of them being equally determinant in the final choice on the investment location. ${ }^{46}$

In particular, some of the most important factors usually taken into consideration by companies before making an investment in addition to taxation are: a country's political and economic stability; its social, physical and communication infrastructures; size and potential growth of the market sector concerned; and cost of labour, availability of a skilled labour force, international outlook of the population, banking system etc. ${ }^{47}$

On the other hand, within the EU it needs to be noticed that almost every Member State is able to offer similar standards with respect to the above-mentioned

42 The dissenting statements of Luxembourg and Switzerland may be found in the OECD Report, pp. 73 et seq.

43 See the OECD Report, p. 17: 'The available data do not permit a detailed comparative analysis of the economic and revenue effects involving low-tax jurisdictions. It has also proven difficult to obtain data on activities involving preferential tax regimes, given the problems in separating their effects from aggregate data in countries with otherwise normal tax systems, and the fact that such regimes often are non-transparent. ... The Committee continues to attach importance to collecting additional data on developments in tax havens and in the use of preferential tax regimes.'

44 OECD Report, p. 35.

45 OECD Report, p. 34. Interestingly, the same paragraph of the Report goes on: 'The Committee accepts that a company may wish to move out of an unfavourable economic or political environment into a more favourable business environment, regardless of the tax incentive offered.'

46 For the main economic sources consulted, see n. 3 above.

47 In conclusion on this point, it is interesting to cite the following paragraph of the OECD Report (p. 17): 'The Committee recognises that some investors may seek to invest in a location with lower rates (and greater after tax return) even if only low public services are available, while others may seek to invest in a location with higher public services even if they have to endure a higher tax burden to finance them. Investors will favour different locations for these reasons but these genuine location decisions have to be distinguished from the type of behaviour which is the focus of this Report.' 
factors, significant differences being present only in the European labour markets due to a different degree of flexibility and availability of skilled employees in the various EU countries. Therefore, ceteris paribus direct taxation bears a heavy weight on the final decision on the investment location.

In addition to that, it appears that certain business sectors are more sensitive to tax considerations than others, especially in open markets like the European one. In particular, mobile business activities (such as financial, insurance and leasing activities) and talented individuals (such as companies' directors, IT specialists and researchers) are most affected by the existence of favourable tax regimes because they may easily move or be shifted to another country, whereas the other factors play a less important role in the decision on their location.

Turning to (or what seems to be) the definition of 'harmful' tax competition in the OECD Report, the key element is the special character of a certain tax measure implemented by a certain country, whose primary result is the erosion of the tax base of other countries: the accent is placed on its nature, effect, and underlying policy.

First of all, the tax measure must be 'special', that is it must constitute a departure from the general tax system of that country in some way. This requirement may cause some practical problems, because it is not always clear what is to be intended as a 'benchmark' system of taxation as opposed to 'deviation' from its general principles.

The second element which is to be analyzed is the spillover effect provoked by that measure. To this end, the actual shift of capital and investments from other countries to the country concerned purely as a result of the implementation of such measure needs to be ascertained. The practical application of this test is very difficult to say the least, because it involves the almost impossible task of gathering economic data from a number of different countries and information on the motivation underlying the shift of capital and investments from one country to another.

Finally, the definition requires an investigation into the country's policy behind the implementation of the tax measure. Consequently, if the described spillover effect is only a side effect coincidental to the pursuance of a desirable goal of domestic fiscal policy, that tax measure is not harmful. For instance, the Report mentions the implementation by a country of tax incentives meant to attract new investments due to the urge to compensate for non-tax disadvantages suffered by it, such as a poor geographical location, lack of natural resources, underdevelopment of certain areas, and the like. ${ }^{48}$

On the other hand, if the implementation of a certain tax measure is driven by the goal of that country of 'deliberately exploiting the interaction of tax systems to erode the tax base of another country' 49 (so-called 'poaching'), it must be considered harmful under the Report. The application of this criterion raises doubts as to the possibility of figuring out the real goals of tax policy aimed at by a country with a certain tax measure. The analysis is once again subjective and it is often difficult to identify the domestic tax policy goals and separate them from the international ones.

In conclusion, considering the EU Code of Conduct and the OECD Report as a whole, the feeling is that the definition of harmful tax competition has been elaborated in a 'deductive' rather than an 'inductive' way. In other words, as it was (and is) very hard to define the theoretical concept of 'harmful' as opposed to 'desirable' tax competition, a general consensus has been reached exclusively on the distortionary economic consequences and effects caused by the former. Consequently, the definition of harmful tax competition has been shaped and adapted to practical criteria identifying harmful economic effects and not vice versa. On the contrary, logically speaking the first step ought to have been to agree at first on a general theoretical concept of harmful tax competition, and only at a later moment to seek the key criteria to be used in the practical individuation of harmful meas-ures. ${ }^{50}$

Perhaps the area of competition law may turn out to be helpful for the purpose of identifying harmful tax competition. In fact, the general definition of the concept of 'competition' between private parties engaged in the same line of business or economic activity may be borrowed and adapted to the peculiarities of (direct) tax law. That concept of competition is described as 'the struggle between rivals for the same trade at the same time; the act of seeking or endeavouring to gain what another is endeavouring to gain at the same time'. ${ }^{11}$

Consequential to such definition is the distinction between 'fair' and 'unfair' competition. The former refers to a lawful and loyal means of achieving the results specified in the general definition. It is encouraged as a means of benefiting both the final customers as to a wider range of products available, lower prices, and better quality and services, and the market as a whole due to automatic mechanisms forcing producers to increase their productivity, efficiency, and quality of their products.

\section{Notes}

48 OECD Report, p. 15.

49 Ibid.

so On this point, the comment of Wright is very appropriate with respect to the OECD Report, at n. 21 above, p. 462: 'Instead, the authors repeatedly assert its existence (i.e., of harmful tax competition) as self-evident and ask the reader to credit the "elephant" tests ("you'll know it when you see it") as the basis for separating beneficial from "harmful" tax practices.' This appears to be confirmed when applying in practice the criteria indicated in both the documents, as will be shown below in the text under Section J.

51 See Black's Law Dictionary (West 1995 - Sixth Edition), under the term 'Competition', p. 284. 
On the other hand, 'unfair' competition entails a dishonest and deceptive attempt of endeavouring to substitute one's own goods or products in the market for those of another by way of fraudulent business practices. ${ }^{52}$ It is strongly fought on the grounds that small producers must be protected against deceiving efforts of big competitors to force them out of business and, in general, to gain market niches not on the basis of improved economic efficiency and productivity but thanks to abusive practices.

These definitions may be transposed with the necessary changes in the field of taxation. The main differences lie in the fact that:

(a) the subjects involved in this struggle are sovereign countries rather than private entrepreneurs;

(b) their endeavour is directed towards gaining a higher share of fiscal revenue deriving from the international division of the taxable base, which arises with respect to taxation of income generated from cross-border activities, as opposed to the goal of gaining a higher share of a market sector; and

(c) the countries most actively engaged in it are small ones, which try to 'redirect' taxpayers from big countries with plenty of resources and infrastructures, and not vice versa.

The EU experience in the area of (fiscal) state aid may also be useful for this purpose. In particular, Art. 92 of the EC Treaty contains a general prohibition of any forms of aid granted by Member States 'which distorts or threatens to distort competition' and 'affects trade between Member States'. However, there are some exceptions in which the granting of an aid is considered compatible with EU law where it promotes the economic development of territories with a low standard of living or underemployment and such aid is not contrary to the common interest. ${ }^{53}$

The practical application of these provisions relies on objective economic parameters, which have the function of identifying the underdeveloped regions needing external support to develop their economy and labour market. Furthermore, the Commission is in charge of monitoring the compliance of (fiscal) aid measures with these indicators, and the European Court of Justice has the task to provide for the legal interpretation on such provisions as well as to decide controversies arising between the Commission and the Member States.

These objective criteria might perhaps be used to assess whether a certain country was urged to implement a certain favourable tax measure in order to help the economic development of certain areas. Moreover, other economic parameters might be agreed upon with respect to the effect of certain tax measures on a country's tax revenue, as well as on the size of foreign direct investment generated through its implementation.

\section{Selected examples of special tax regimes in EU and OECD countries}

\section{A. General}

This section describes certain special tax regimes implemented by EU and OECD countries that may possibly be labelled as 'harmful' tax competition according to the criteria laid down in both the Code of Conduct and the Report. It is intended to provide an example and a practical guidance of how such criteria apply.

These regimes have been selected on the basis of their relevance and probable effectiveness in attracting foreign investments to the countries concerned. Particular emphasis has been placed on their relation with the 'benchmark' tax system of the country concerned.

\section{B. Belgium: coordination centre regime ${ }^{54}$}

One of the first special tax regimes implemented in Europe in order to attract foreign direct investments was introduced by Belgium in 1982. It was meant to encourage divisions of multinational companies engaged in the development and centralization of certain activities for the benefit of the group to locate such activities in Belgium. ${ }^{55}$ Generally speaking, the main difference of this tax regime as compared to the normal Belgian corporate tax regime is the method of computation of taxable profits.

As a general rule, under the Belgian Tax Code both resident and foreign companies must calculate their taxable income on the basis of their gross receipts as shown on the financial statements. The latter are then adjusted with appropriate deductions in order to calculate their net taxable income to be subjected to the corporate tax rate of 40.17 per cent.

Conversely, the computation of taxable profits under the special regime on coordination centres is based on the 'cost-plus' method.

\section{Notes}

52 See Black's Law Dictionary (West 1995 - Sixth Edition), under the term 'Unfair Competition', p. 1528.

53 Article $92(3)$ (a) and (c) of the EC Treaty.

54 The following bibliography was consulted for the tax system and the coordination centre regime implemented in Belgium: The Taxation of Companies in Europe: Belgium, International Bureau of Fiscal Documentation, Amsterdam loose-leaf 1997; Ministry of Finance, Corporate Income Tax, as downloaded on the World Wide Web site of the Belgian Ministry of Finance < www.minfin.fgov.be > ; Ministry of Finance, Special Tax Regimes: Co-ordination Centres, as downloaded on World Wide Web site of the Belgian Ministry of Finance < www.minfin.fgov.be >; P. Vanhaute, 'Co-ordination Centers in Belgium', Intertax 1985/3, p. 64; F. Dierckx, 'Headquarter Offices in Belgium', European Taxation, 1986/10, p. 307; Ernst \& Young, Belgian Special Tax Regulations on Co-ordination Centers, as downloaded on the World Wide Web site of Ernst \& Young < www.ey.be/EYEN/eyhome.htm >.

55 The special legislation on Belgian coordination centres was introduced by Royal Decree No. 187 of 30 December 1982, subsequently amended by Royal Decree of 20 December 1984. 
Belgian coordination centres (hereinafter: BCCs) may take the form of either a subsidiary or a permanent establishment established in Belgium by a foreign company pertaining to an international group. For this purpose, it is required that the group has subsidiaries in at least four continents and that it derives a certain minimum turnover outside Belgium. Furthermore, the BCC is required to have at least ten full-time employees by the end of the second year since its start of operations.

In order to qualify, BCCs must pursue the statutory goal of developing or centralizing eligible activities for the benefit of the international group of companies. They include a number of support and financial activities rendered in favour of other group companies so as to facilitate the group's organizational structure and the performing of certain activities that may reduce the overall costs borne by the group as a whole.

In particular, eligible support activities include advertising and sales promotion, information collection and provision, and insurance and reinsurance activities. Eligible financial activities include the granting of advances and loans, currency exchange transactions, factoring and leasing, and financial management.

This special regime allows BCCs the possibility to compute their taxable profits on the basis of the costplus method, i.e. as a certain percentage of their operating expenses incurred to perform eligible group activities to be set by the Belgian tax authorities. This percentage is usually fixed at 8 per cent of their operating expenses. The latter do not include personnel expenses and financial expenses, which are therefore not taken into account in the computation of the BCCs' taxable base.

The notional taxable amount resulting from the application of the cost-plus method is then subject to the standard corporate tax rate of 40.17 per cent.

In practice, this regime provides BCCs with legal certainty as to the prices of intra-group transactions. As their receipts are low as compared to the expenses incurred to centralize group activities and in addition they are derived from transactions concluded with related parties, it may be difficult to calculate the amount of taxable profits according to their financial statements. Consequently, the BCCs' taxable amount would be likely to be very low and there would be the possibility for the tax authorities to challenge the prices set with respect to the intra-group transactions under the transfer-pricing legislation.

This regime eliminates these problems and provides
BCCs with legal certainty since the mark-up charged to their related group companies for the rendering of the centralized activities will be accepted by the Belgian tax authorities as long as it reflects the 8 per cent margin agreed upon with them.

There are a number of other tax incentives available to BCCs: exemption from withholding taxes on passive income (i.e. dividend and interest income) remitted to non-resident recipients; exemption from withholding tax on interest on deposits; exemption from registration duties and exemption from real property withholding tax.

The application of this special regime is subject to the prior approval by the Belgian tax authorities, which are to assess the fulfilment of the prescribed conditions and decide on the percentage to be applied to the notional tax base.

\section{Ireland: the IFSC regime r $^{56}$}

In 1987, Ireland implemented a special tax regime in order to attract foreign direct investments by multinational groups in favour of companies operating in the International Financial Services Centre (hereinafter: IFSC) located in the Custom House Docks Area in Dublin. ${ }^{57}$

This special regime derogates from the Irish benchmark tax system in that the total tax burden imposed on eligible IFSC companies is much lower than that imposed on the other domestic corporations.

Under the general tax system, resident companies are subject to corporate tax on their worldwide profits at a rate of 32 per cent. Non-resident companies (i.e. local branches of foreign companies) are subject to the same rate exclusively on their profits derived in Ireland. The standard rate is lowered to 10 per cent with respect to profits derived from the sale of goods manufactured in Ireland by companies subject to Irish corporate taxation: this is usually referred to as the 'manufacturing relief'. ${ }^{58}$

On the other hand, the IFSC regime is available exclusively to resident companies (i.e. subsidiaries) of multinational groups and permanent establishments of foreign companies established in the Centre. Furthermore, the tax incentives provided by the IFCS regime apply exclusively to income deriving from the carrying on of eligible activities performed within the Centre and solely in favour of persons not ordinarily resident in Ireland.

Eligible activities which may be carried out by IFSC companies include: banking activities; performance of

\section{Notes}

56 The following bibliography was consulted for the tax system and the IFSC regime implemented in Ireland: The Taxation of Companies in Europe: Ireland, International Bureau of Fiscal Documentation, Amsterdam, loose-leaf 1997; Ernst \& Young, International Tax Library: Ireland, 1997, as downloaded from the World Wide Web site of Ernst \& Young < www.eyi.com > ; C. Haccius, Ireland in International Tax Planning, International Bureau of Fiscal Documentation 1995; S. Ozelli \& E. J. Hillman, 'Ireland: Gateway of Choice to Russia', Tax Notes International, 19 August 1996, p. 559; J. A. Moran, 'Extended Date for IFSC Projects Boosts Tax Advantages', The Journal of International Taxation 1995/10; Walley, Yunich \& Byrne, 'Ireland and the IFSC are Becoming Europe's New Funds Management Center', The Journal of International, Taxation 1994/8.

57 The IFSC regime was introduced by s. 30 of the Finance Act of 1987.

58 The 'manufacturing relief' was introduced by the 1980 Finance Act in order to promote manufacturing activities carried on in Ireland, which would in turn favour an increase of employment in the country. 
international financial services; insurance and reinsurance activities; treasury and global fund management; leasing and factoring activities; ancillary activities relating to any of the above.

Income arising in connection with one of these activities enjoys a number of direct (and indirect) tax incentives. First of all, the applicable corporate tax rate is reduced to 10 per cent instead of the standard one of 32 per cent. ${ }^{59}$ Furthermore, there is an exemption from withholding tax on dividends and interest paid by IFSC companies to non-resident recipients.

Other incentives are granted in the form of special deductions or investment allowances. In particular, IFSC companies are entitled to an immediate expensing (i.e. 100 per cent deduction in the first year) with respect to the purchase of new equipment and the construction or refurbishment of buildings to be used in the carrying on of their business activity within the Centre. In addition, a 200 per cent deduction is granted for rent expenses paid in connection with buildings or premises located in the Centre and used to perform their business activity therein.

Lastly, IFSC companies are eligible to an exemption from stamp duties for most financial transactions and to an exemption from local property taxes for a period of ten years.

The application of the IFSC regime does not apply automatically once all of the prescribed conditions are met. Eligible companies must seek prior authorization by the Industrial Development Agency ('IDA'), which issues the required licences necessary to operate in the IFSC on the basis of the potential benefits brought about by the investment projects to the Irish economy and local employment.

The IFSC regime is due to expire on 31 December 2005. Furthermore, as from 31 December 2000 no new authorizations may be issued by the IDA in favour of companies establishing in the Centre.

It is worth noting that this regime constitutes state aid within the meaning of Art. 92 of the EC Treaty, and that it has been authorized by the European Commission under this provision. ${ }^{60}$ Particular problems, therefore, are likely to arise with regard to its qualification as 'harmful' under the Code of Conduct.
In fact, even though it is a special regime reserved exclusively to those IFSC companies mainly pertaining to foreign-based multinational groups, it is hard to foresee how it may be dismantled in consideration of the previous Commission's approval on Ireland's economic development grounds. ${ }^{61}$

\section{Netherlands: distribution centre regime ${ }^{62}$}

An administrative practice has developed in the Netherlands in favour of local distribution centres of multinational companies since 1985.63 Under the Resolution, the taxable profits of the distribution centres may be calculated in a notional way according to the cost-plus method rather than on the basis of their financial statements, as required under the standard Dutch corporate tax rules.

Both subsidiaries incorporated under Dutch law and local permanent establishments of foreign companies qualify for this special regime. Eligible activities that may be performed by distribution centres are certain activities of a supporting, auxiliary or preparatory nature, such as: storing and displaying of a group's products; sorting, testing, repairing and packaging of a group's products; fulfilling of certain administrative formalities; and the provision of local transportation.

As the above activities are to be performed for the exclusive benefit of group companies and involve high amounts of expenses borne by the distribution centres, their taxable base may turn out to be very low under the normal rules and there may arise transfer-pricing problems with respect to the profit margins charged to the other group companies. In order to avoid these problems, under the Resolution the amount of taxable profits acceptable by the tax authorities without undertaking a transfer-pricing proceeding must be equal to a certain percentage of the operating expenses borne by the distribution centre.

The operating expenses taken into account in the computation of the distribution centres' notional taxable base are accommodation costs, office expenses, and remuneration and cost allowances for employees. On the other hand, costs with a disbursement

\section{Notes}

59 Technically speaking, the 10 per cent rate applies due to a legal presumption that eligible activities performed in the IFSC in favour of non-resident persons constitute 'manufacturing' activities covered by this preferential tax rate applicable under the 'manufacturing relief'.

60 See the Commission's Reports on Competition Policy of 1987 and 1990, and the state aid plans under which the Commission has raised no objection, in the OJ No. C15 of 21 January 1992, p. 5, and the OJ No. C390 of 31 December 1994. As mentioned above, Art. 92 provides for the possibility to allow regional state aid in any form (including through a country's tax system) on the grounds of the need to help economic development and employment in selected depressed areas, and it constitutes the legal basis under which the European Commission authorized the IFSC regime.

61 In other words, the goal of attracting foreign investors by trying to affect their location decision was not the only underlying reason driving the government to implement the IFSC regime, the main one being the economic development of that area.

62 The bibliography consulted for the tax system and the distribution centre regime implemented in the Netherlands is: The Taxation of Companies in Europe: Netherlands, International Bureau of Fiscal Documentation, Amsterdam, loose-leaf 1997; Ministry of Finance, Taxation in the Netherlands, as downloaded from the World Wide Web site of the Dutch Ministry of Finance < www.minfin.nl/Uk/taxation/taxneth/taxneth.htm >; G. te Spenke, Taxation in The Netherlands, (Kluwer 1995); Loyens \& Volkmaars (Tax Advisors), 'Netherlands: Tax Treatment of Certain Activities of Multinational Enterprises', Intertax, 1986/6-7, p. 144; A. M. Huyghe, 'The Special Tax Regime for Distribution Centers - a Comparison with the Tax Regime for Dutch Distribution Centers and with Similar Tax Regimes in Belgium', Intertax, 1992/2, p. 97.

63 This administrative practice was introduced by the Resolution of the Dutch Ministry of Finance No. 084.2737 of 25 April 1985 (hereinafter: Resolution), concerning the 'Tax Treatment of Certain Activities of Multinational Enterprises' (i.e. Resolutie Staatssecretaris van Financien: 'Fiscale behandeling van bepaalde activiteiten in concernverband'). 
character are explicitly excluded, such as retributions, fees paid on behalf of group companies to unrelated parties for their services (i.e. transportation expenses and insurance costs), and court fees.

The applicable mark-up must be agreed upon in advance with the Dutch tax authorities on a case-bycase basis and varies depending on the nature of activities rendered by the distribution centres, on the size of their business risk and on their actual contribution to the total profits of the group. The standard percentage as laid down in the Resolution is set at 5 per cent of the notional tax base, which may become as high as 10 per cent if higher commercial risks are borne by the distribution centre.

The taxable rate applicable on the distribution centres' taxable base computed under the cost-plus method is the standard corporate rate of 35 per cent.

This regime has the aim to provide distribution centres with legal certainty as to their tax liability and to prevent transfer-pricing disputes that may otherwise arise with respect to intra-group transactions. This method turns out to be advantageous to distribution centres especially due to the fact that the mark-up is usually set at a low level (5 per cent) and that significant costs are not taken into account in their notional taxable basis.

\section{E. France: distribution centre regime ${ }^{64}$}

In 1996, the French tax administration published a set of guidelines containing a special regime in favour of distribution centres of multinational companies (centres de logistique, hereinafter: CL). ${ }^{65}$ Indeed, such regime had already existed for a long time due to an unpublished administrative practice, but had never been formalized in an official document.

Once again, it may be affirmed that the tax rules applicable to eligible CLs differ from the standard corporate tax rules in that their taxable base is computed on a notional basis relying on the cost-plus method rather than on the basis of the company's financial statements. As it may be difficult to calculate the amount of their taxable profits due to the fact that their services imply mainly expenses and are performed (almost) exclusively in favour of group companies, their taxable income is calculated by applying a certain percentage (mark-up) to the operating expenses incurred by them.

The special tax regime applicable to CLs is available for French companies or permanent establishments of foreign companies which form part of an international group. The group may have its parent company located either in France or abroad and is deemed to comprise all companies directly or indirectly controlled by the parent for at least 50 per cent of their voting rights.

The only activities that may be carried out by CLs are the warehousing, packaging, labelling and distributing of group products, and the rendering of relating administrative services for the exclusive benefit of group companies. Hence, CLs must be involved in preparatory or secondary activities and are prohibited from taking part in manufacturing or marketing activities.

Furthermore, CLs must perform their services only in favour of or on behalf of group companies. Therefore, if they render services to companies outside the group, income derived therefrom is subject to the standard rules of taxation. Additional restrictions to CLs' eligible activities include the prohibition to engage in the acquisition or resale of finished group products as well as the processing of raw materials and semi-finished products.

The tax treatment of CLs relies on the application of the cost-plus method. In particular, certain expenses incurred by them are subject to a certain mark-up percentage, which is considered to reflect the arm'slength principle for transactions concluded with other group companies.

The taxable base is constituted by their operating expenses with the exclusion of those expenses incurred on behalf of other group companies or with a disbursement nature (débours), which are not includable in their base.

The total amount of taxable profits is determined by applying the percentage agreed upon with the French tax authorities to such notional taxable base. This percentage ranges between 6 per cent and 12 per cent and is usually set at 8 per cent of the CL's operating expenses.

The amount of taxable income resulting from this computation is then subject to the standard French corporate rate of 33.33 per cent plus the applicable surcharges.

The French regime on CLs presents no substantial differences from the competing systems implemented by the other countries analyzed. It is interesting, however, to note that the French government made a move towards openness and transparency of this regime by publishing the conditions for the granting

\section{Notes}

64 The following bibliography was consulted for the tax system of France and the distriburion centre regime: The Taxation of Companies in Europe: France, International Bureau of Fiscal Documentation, Amsterdam, loose-leaf 1997; KPMG, Tax Facts: France, 1997, as downloaded on the World Wide Web site of KPMG < www.tax.kpmg.net >; P. H. Revault \& F. Rontani, 'France Extends Rulings for Cost-Plus Taxation to Headquarters of Multinational Groups', Tax Notes International, 3 March 1997, p. 761; P. J. Douvier, 'Clarification of Tax Regime for Headquarters and Distribution Centres', European Taxation 1997/4, p. 131; M. A. Deysine-de Bourqueney \& R. Jouffroy, 'New Tax Developments to Encourage Foreign Investments in France: Headquarters, Logistics Centres and Taxation of Expatriates', European Taxation, 1997/5, p. 219; P. Y. Bourtourault \& M. Mbwa-Mboma, 'New Tax Treatment of Logistics Centres in France', Intertax, 1997/10, p. 342.

65 The regime on the French distribution centres is contained in the Guidelines BOI 13G-1-97 of 21 January 1997. The guidelines also contain a favourable regime in favour of headquarters of multinational companies established in France and of employees working for both distribution centres and headquarters. The latter regimes, however, are not explained in the text. 
of the favourable rulings as well as its procedural rules. This is a good example of how difficult it would have been to find out the administrative practice that had already been in effect before the publication of the guidelines due to its hidden character. Despite that, the tax measure in question may still be labelled as potentially harmful according to some of the criteria contained in both the Code of Conduct and the OECD Report (see below).

\section{F. Netherlands: the CFM regime ${ }^{66}$}

In 1997, the Dutch government introduced a special regime in favour of finance companies (i.e. concern financieringsmaatschappij, hereinafter: CFM) established in the Netherlands and belonging to a multinational group. ${ }^{67}$ This regime was meant to improve the tax climate for those international groups of companies wishing to centralize their financing activities performed for the benefit of the group so as to reduce the financial risks borne by the various group companies.

Under the general corporate tax system, resident companies are taxed in the Netherlands on their worldwide profits at a rate of 35 per cent. Foreign companies are subject to the same rate on their taxable income, which is limited to that derived from Dutch sources. The amount of profits to be included in the companies' annual taxable income is calculated on the basis of their financial statements. In particular, the amount of gross profits as recorded on their balance sheet must be adjusted by subtracting the applicable deductions in order to calculate the net amount of taxable income.

For a better understanding of the CFM regime, it is necessary to outline the corporate tax rules on the formation of reserves. Only a limited number of taxfree reserves may be set up provided certain conditions are met. These are the expenditure equalization reserve, ${ }^{68}$ the replacement reserve, ${ }^{69}$ and the risk reserve. ${ }^{70}$

The main feature of the CFM regime is that eligible companies are entitled to form a tax-free financial risk reserve (hereinafter: FRR) meant to cover the risks arising from the carrying on of financing activities rendered for the benefit of the group. This allows a significant tax deferral on the amounts of income contributed to the FRR, which will be taxed only at the later moment of their release from the reserve. On top of that, the subsequent release of funds from the FRR may enjoy a special tax treatment resulting in the application of an effective tax rate much lower than the standard one.

A number of conditions must be fulfilled by a company in order to acquire the CFM status. First of all, it must belong to an international group of companies, i.e. to a group having companies in at least two continents or at least four countries. Furthermore, it must perform eligible activities for the exclusive benefit of group companies and not for third parties, and such activities must be performed exclusively from the Netherlands. For this purpose, the central finance management function of the group must be carried out in the CFM, and strict substance requirements apply. Lastly, it must perform only a very limited share of its activities in favour of Dutch group companies, so as to prevent any potential attempt to erode the Dutch taxable base through tax-avoidance schemes.

The eligible activities that may be performed by CFMs include a number of intra-group financing activities, such as granting of advances and loans, leasing and factoring activities, controlling activities, financial and administrative activities. In addition, activities relating to short-term portfolio investments are allowed under certain conditions.

Income deriving from the aforementioned eligible activities may be contributed to the FRR for a maximum of 80 per cent of its amount, only 20 per cent being thus subject to the standard corporate tax of 35 per cent. The effective tax rate borne by a CFM on its eligible financial activities is therefore at the first instance reduced to 7 per cent. ${ }^{71}$

As observed, the release of funds from the FRR enjoys a special tax treatment in certain cases. In particular, there are three different tax treatments in respect of releases depending on the underlying situation giving rise to them.

First, a release may take place tax-free if it is meant to:

(i) finance investments undertaken by the group (i.e. acquisitions of new companies);

(ii) finance investments of the group exceeding the

\section{Notes}

66 The following bibliography was consulted for the Dutch CFM regime: R. A. van der Laan, 'Abour Durch Finance Centres and More', Intertax 1996/5, p. 208; van der Kloot \& O. Teunissen, 'Netherlands Chamber Approves Tax Bill Affecting Multinational Groups', Tax Notes International, 28 October 1996, p. 1419; M. van Casteren \& D. Hofland, 'Dutch Rules on Group Finance Companies and Anti-Base-Erosion Measures Analyzed', Tax Notes International, 3 March 1997, p. 743; R. A. van der Laan, 'About Dutch Finance Centres and More (Continued): The Interest Deduction Restrictions', Intertax, 1997/11, p. 399. For a thorough comment of the CFM regime, see P. J. Wattel, 'Belastingconcurrentie, staatssteun, de EG-gedragsCode en de Nederlandse CFM', Nederlands tijdschrijft voor Europees recht, 1998/1-2, p. 17.

67 The CFM regime was introduced by Law of 13 December 1996, published in Staatsblad No. 651 of 24 December 1996.

68 This reserve is meant to cover expenditures that pertain to more than one taxable year and are incurred by a company in its business activity. For instance, a survey reserve for a once-in-four-years survey of a ship falls in this provision.

69 This reserve may be formed to defer taxation on capital gains on business assets that have been sold or damaged and paid for by insurance proceeds. The assets concerned must be replaced within four years, and the amount contributed to the reserve must be deducted from the purchase price of the replacing asset.

70 This reserve may be formed to cover risks that have not been insured by the taxpayer and that are usually insured by at least 30 per cent of the taxpayers.

71 i.e., 20 per cent (percentage of income subject to full corporate taxation) $\times 35$ per cent (ordinary tax rate). 
ordinary risk (i.e. investments undertaken in areas politically unstable or subject to high currency fluctuations);

(iii) finance legal liabilities of other group companies under certain conditions.

In these cases the ultimate tax rate borne by the CFM on these reinvested profits remains at 7 per cent.

The second type of release of funds is referred to as 'voluntary' and occurs upon election of the CFM. In this case, the amounts previously set aside in the FRR are included in the CFM's taxable income in five equal instalments and subject to a special tax rate of 10 per cent. Therefore, the effective tax rate borne by income contributed and then voluntarily released is 15 per cent. $^{72}$

The third situation is the 'mandatory' release of funds from the FRR, which takes place upon: (i) liquidation of the CFM; (ii) shift of fiscal residence; or (iii) subsequent failure to meet the prescribed conditions. In this event, the release is taxed at the full statutory rate of 35 per cent. Even then, a significant tax deferral may have been enjoyed by the CFM for the time during which the income was tied up in the FRR.

The application of the CFM regime is subject to the approval of the tax authorities, which issue the authorization upon assessment of the satisfaction of all the legal conditions. No deadline has been set with respect to the application of the CFM regime, but the authorizations granted carry a time-limit of ten years.

\section{G. Luxembourg: the 1929 holding company ${ }^{73}$}

Luxembourg is one of the most advantageous European locations for the establishment of holding and financial activities by multinational companies. Its oldest special regime was introduced for this purpose back in 1929 and features an exemption from corporate taxation in favour of eligible entities. In order to understand the speciality of this regime, it is first necessary to outline the ordinary system of taxation in Luxembourg with respect to intercorporate dividend distributions.

Generally speaking, Luxembourg has adopted a classical method of taxation of dividends, i.e. they are subject to corporate tax in the hands of both distributing company and receiving company at the standard rate of $31.2^{74}$ per cent and, in addition, to a municipal business tax on income (usual rate: 10 per cent) and to a net worth tax (rate: 0.5 per cent).$^{75}$

Furthermore, dividends are subject to a withholding tax of 25 per cent upon distribution to the receiving company, which in turn is entitled to a credit for the full amount to be used against its corporate tax liability. On the other hand, the 25 per cent withholding tax is final and may not be refunded if the receiving company is not resident in Luxembourg, unless the Parent-Subsidiary Directive or a tax treaty provides for an exemption, a lower rate, or the possibility to claim a refund.

In order to mitigate the consequences of the classical method, a participation exemption is granted in favour of resident companies forming part of the same group provided some conditions are met. In particular, the receiving company must: ${ }^{76}$ (i) hold a participation in the outstanding capital of the distributing company of at least 10 per cent or whose acquisition price has been at least LUF 50 million; (ii) hold such participation for an uninterrupted period of at least one year prior to the distribution; (iii) be subject to corporate taxation in Luxembourg. As to the distributing company, it is required that it be subject to corporate tax on its profits in Luxembourg or to a foreign country's corporate tax similar to the Luxembourg one. ${ }^{77}$

The '1929 holding company' regime was introduced in order to favour the establishment in Luxembourg of companies engaged exclusively in the management of shareholdings in other companies. ${ }^{78}$

Eligible entities must be incorporated in Luxembourg as joint stock companies, limited liability companies, partnerships limited by shares or cooperative companies. There are only a few activities that may be carried on by 1929 holding companies: (i) management of shareholdings in domestic and/or foreign companies; (ii) management of government or private securities; (iii) supply of advances and loans in favour of companies in which a 'reasonable' direct participation is held; (iv) management of intangible rights (provided certain conditions are met).

Explicit restrictions are applicable with respect to the activities of 1929 holding companies. In particular, the latter are prohibited from (i) exercising any kind of commercial or industrial activity, or having an office open to the public; (ii) owning immovable property

\section{Notes}

72 i.e., 7 per cent (see in the text) +8 per cent $(80$ per cent (percentage of income contributed to the FRR) $\times 10$ per cent (preferential tax rate applicable upon voluntary release)).

73 The bibliography consulted for the Luxembourg tax system and the 1929 holding company and the soparfi regimes is: The Taxation of Companies in Europe: Luxembourg, International Bureau of Fiscal Documentation, Amsterdam, loose-leaf 1997; KPMG, Tax Facts: Luxembourg, 1997, as downloaded on the World Wide Web site of KPMG < www.tax.kpmg.net>; N. Shelton \& F. de Petter, 'Holding Companies: a Review of the New Luxembourg Rules and Six Other Countries', European Taxation 1991/3; E. Bruin, 'The New Holding Company Modern Fashion of an Older Principle', European Taxation 1991/4.

74 The statutory corporate tax rate is 30 per cent plus a surcharge for the employment fund of 4 per cent.

75 Therefore, the standard corporate tax burden (excluding the net worth tax on capital) is equal to 37.45 per cent.

76 The Luxembourg participation exemption is contained in Art. 166 of the Luxembourg Income Tax Act (LIR).

77 A foreign corporate tax is considered similar to the Luxembourg corporate income tax where its tax rate is no less than 15 per cent.

78 This special regime was introduced by Law of 31 July 1929, as subsequently amended by Law of 12 July 1977. 
other than that necessary to carry on the activity; (iii) charging fees for the services provided; (iv) borrowing money exceeding certain ceilings. ${ }^{79}$

Several tax privileges are accorded to 1929 holding companies. They are exempt from corporate taxation in Luxembourg and are not required to withhold taxes on payments of dividends regardless of the receiving company's country of residence. Furthermore, they are exempt from the net worth tax and from the municipal business tax on companies' income normally due by the other corporations resident in Luxembourg.

Other tax benefits granted to 1929 holding companies include an exemption from tax on capital gains realized on qualifying shareholdings, an exemption from corporate tax upon their liquidation, and an exemption from tax on liquidations of qualifying subsidiaries.

1929 holding companies are subject to an annual subscription tax levied at a rate of 0.2 per cent on the value of the shareholdings owned, which may in no case be lower than LUF $2,500 .{ }^{80}$ In addition, they are liable to a tax on capital contributions equal to 1 per cent of their value, which may be waived under certain circumstances.

\section{H. Spain: the ETVE ${ }^{81}$}

In 1997 Spain introduced a special tax regime in favour of domestic holding companies (i.e. Entidad de Tenencia de Valores Extranjeros, hereinafter: ETVE). ${ }^{82}$ This regime was introduced with a goal to increasing the international competitiveness of the Spanish tax system and to offering an attractive alternative to the other favourable systems dealing with international holding and financing companies already available within the EU.

The ETVE regime features a tax treatment with respect to eligible income derived by ETVEs which deviates from the standard tax regime applicable in Spain. In particular, under Spanish tax law an imputation system relying on the credit method is used to relieve economic double taxation in respect of intercorporate distributions of income between companies. Thus, dividends received by a Spanish company from a foreign company are subject to taxation in Spain, with a direct credit granted for the withholding taxes borne by such distributions and an indirect tax credit for the underlying profits taxes paid in the foreign country by the distributing company. ${ }^{83}$

Certain conditions are laid down for the granting of the indirect tax credit with respect to both the Spanish parent company and the foreign distributing company. More specifically, the former must: (i) be subject to corporation tax in Spain; (ii) be organized as a joint stock company, a limited liability company, or a general partnership limited by shares; (iii) have held a direct or indirect participation of at least 5 per cent in the capital of the foreign company for an uninterrupted period of one year. As to the latter, they must: (i) derive income from business activities (i.e. actividades empresariales); (ii) be resident in a country with which Spain has concluded a tax treaty containing an adequate exchange of information provision; (iii) not be resident in a tax haven included in the lists drawn up by the Spanish tax administration. ${ }^{84}$

Furthermore, where the conditions of the ParentSubsidiary Directive apply, i.e. the Spanish parent has held for an uninterrupted period of more than one year a participation of at least 25 per cent in another EU company, the dividends distributed by the latter are exempt from withholding in its country and are granted a credit in Spain for the taxes borne in the country of the subsidiary regardless of the fulfilment of the above conditions.

Lastly, it is worth noting that outbound dividends paid by Spanish companies to foreign companies (other than EU parents qualifying under the Parent-Subsidiary Directive) are subject to a withholding tax of 25 per cent upon distribution, unless an applicable tax treaty states otherwise.

Unlike the general system, the ETVE regime features a tax-free treatment in respect of qualifying dividends and capital gains derived by ETVEs.

There are some conditions that must be met by a company in order to acquire the ETVE status. Both companies incorporated in Spain and branches of foreign companies are eligible to become ETVEs provided their main statutory goal set out in their

\section{Notes}

For this purpose, the 1929 holding company legislation sets strict ratios to be complied with by eligible companies, such as a 1:3 debt/equity ratio and a 10:1 ratio for bonds issued.

80 However, in case the amount of dividends distributed by them during the fiscal year exceeds 10 per cent of their share capital, the taxable base for the purpose of the subscription tax is equal to ten times the value of the dividends distributed rather than to the value of their shareholdings.

81 The following bibliography was consulted for the Spanish tax system and the ETVE regime implemented in Spain: The Taxation of Companies in Europe: Spain, International Bureau of Fiscal Documentation, Amsterdam loose-leaf 1997; KPMG, Tax Facts: Spain, 1997 as downloaded on the World Wide Web site of KPMG < www.tax.kpmg.net >; J. J. Terraza \& N. J. Muñiz, 'New Holding Company Regime', European Taxation, 1997/4, p. 145; J. Calderón, 'Amendments to Spanish Methods of Avoiding International Economic Double Taxation and the Tax Treatment of Spanish Holding Entities', Intertax 1997/5, p. 190; J. C. Taylor \& C. E. Hannum, 'Spanish Holding Company Legislation Eclipses Netherlands and Luxembourg', Tax Notes International, 14 July 1997, p. 91; J. Albós, 'Tax System for Holding Companies for Foreign Securities', Intertax 1998/4, p. 141.

82 The ETVE regime was introduced with Law 10/1996 of 20 December 1996, which became effective on 1 January 1997 and was transposed into Arts. 129 through 132 of the Spanish Corporate Income Tax Act (hereinafter: CITA). The technical details relating to the practical application of this regime were enacted by the Corporate Tax Regulation contained in Royal Decree 537/1997 of 14 April 1997, published in the Spanish Official Gazette of 24 April 1997.

83 Article 30 CITA.

84 The CFC rules are contained in Art. 121 of CITA. As a consequence of this requirement, the foreign distributing company must be subject to a tax on its profits in the foreign country similar to the Spanish corporate tax and whose corporate tax rate is equal to at least .75 per cent of the Spanish one. 
by-law is the administration and the management of equity participations in non-resident entities.

Eligible dividends and capital gains are those derived by ETVEs in connection with direct or indirect participations in the non-resident entities: (i) of at least 5 per cent of the latter's outstanding share capital; and (ii) held for an uninterrupted period of at least one year. Furthermore, ETVEs must have enough 'substance' in Spain, i.e. a real organizational structure and adequate facilities.

Some conditions must be fulfilled by the foreign entities whose shareholdings are managed by the ETVEs. In particular, they must: (i) be subject to a system of taxation similar to the Spanish one without enjoying a tax-exempt status, regardless of the actual tax rate applicable to their profits; (ii) not be resident in a country considered as a tax haven under Spanish CFC legislation; and iii) derive at least 90 per cent of their profits from business activities carried on outside Spain.

As to the tax incentives granted to ETVEs, they benefit from a participation exemption in respect of dividends received by and capital gains arising from the disposition of qualifying shareholdings in foreign companies. This exemption is to be considered special because the normal method used to relieve international economic double taxation with respect to inbound dividends is the credit method.

In addition, ETVEs are entitled to an exemption from the 25 per cent withholding tax normally due on outbound transfers of dividends, due to a legal presumption that they are derived from foreign sources. ${ }^{85}$ If such distributions were not considered to have been derived outside Spain, they would normally be subject to the withholding rate of 25 per cent upon transfer abroad, unless the exemption under the Parent-Subsidiary Directive (i.e. exemption from Spanish withholding tax for distributions to qualifying EU parent companies) or a lower (or nil) rate under a tax treaty stated otherwise. ${ }^{86}$

\section{Portugal: the Madeira Free Zone ${ }^{87}$}

A different scenario may be found in Portugal and Spain, where the goal of attracting multinational companies has not been pursued through the implementation of special tax regimes by the central government, but through the creation of special areas covered by an autonomous tax system implemented by local authorities. In these cases, the speciality lies in that there are several tax incentives granted at local level rather than 'deviations' from the notional tax systems applicable in these countries.

A special area with a number of tax benefits granted to companies and individuals operating therein was set up in the Madeira archipelago in 1980. This archipelago is formed by four islands, two of which are inhabited (Madeira, whose capital is Funchal, and Porto Santo), and two small islands without population.

The Portuguese Constitution grants Madeira a limited political and administrative autonomy under which the archipelago's institutions are entitled to implement autonomous tax legislation, which must nevertheless receive the approval of the Central Parliament. ${ }^{88}$

It was under this power that the Madeira Free Zone (i.e. Zona Franca Madeira, hereinafter: ZFM) was first established in 1980 in the light of the accession of Portugal to the then EEC. ${ }^{89}$ However, it took several years before the start of operations due to complex negotiations with both the central government of Portugal and the EU institutions, which stressed the importance of the creation of the ZFM so as to favour the economic development of that area. ${ }^{90}$

In order to enjoy the tax benefits of the ZFM, a foreign company must establish either a subsidiary or a local permanent establishment in the archipelago. Also Portuguese companies located in mainland Portugal may set up companies in Madeira, but they may not benefit from all of the tax incentives, some of them being exclusively available for foreign-based companies. ${ }^{91}$

Eligible activities that may be carried out in the ZFM include: (i) industrial activities and similar, such as manufacturing, packaging, assembling, storing and handling of goods; (ii) financial, banking, and insurance and reinsurance activities; (iii) trading, management, and trusts activities; (iv) holding activities, provided they relate to shareholdings of com-

\section{Notes}

85 Article 131 CITA

86 Conversely, in case of non-eligible dividend and capital gain distributions, ETVEs are subject to the standard domestic corporate tax system and to the withholding taxes levied upon their remittance abroad.

87 The following bibliography was consulted for the tax system and the Madeira Free Zone regime implemented in Portugal: The Taxation of Companies in Europe: Portugal, International Bureau of Fiscal Documentation, Amsterdam, loose-leaf 1997; KPMG, Tax Facts: Portugal, 1997, as downloaded on the World Wide Web site of KPMG < www.tax.kpmg.net > ; de Juan y Ledesma A., 'Canary Islands and Madeira Free Zone Regimes: Some Issues and Prospects', European Taxation 1997/5, p. 173; F. de Sousa Da Camara, 'Madeira Free Zone: Tax Exemptions and Financial Incentives', European Taxation 1990/4; F. de Sousa Da Camara, 'Madeira Free Zone Legislation Amended', European Taxation 1994/1; Garcia Rubi, 'Madeira's Appeal Measures', Intertax 1996/9, p. 58.

88 Articles 106(2) and 18(1)(i) of the Portuguese Constitution.

89 The ZFM regime was introduced by Decree-Law 500/80 of 20 October 1980 and by the subsequent Decrees No. 53/82 of 23 August 1982, No. 352-A/88 of 3 October 1988, and No. 264/90 of 31 August 1990.

90 See the Competition Policy Reports of the Commission of the years 1986, 1989, 1991, 1994, and 1995. In particular, the economic indicators relating to the archipelago showed a deep underdevelopment of the region and the need to implement measures to reduce this phenomenon.

91 The current analysis will focus exclusively on the benefits granted to foreign-based companies, because the incentives were aimed mainly at attracting the latter rather than at providing domestic companies with a special regime. 
panies not located in Portugal or in the European Union; ( $\mathrm{v}$ ) shipping activities.

A number of tax incentives are granted to eligible companies operating in the ZFM in the areas of both direct and indirect taxation.

ZFM companies enjoy a total exemption from corporate income tax in respect of income arising in connection with eligible activities carried out within the ZFM or with transactions concluded with nonresidents of Portugal. In addition, shareholders of ZFM companies are exempt from withholding tax on dividends and interest received from them.

They are also exempt from the transfer tax otherwise due on the disposal of real estate and on transactions relating to shares, quotas, participation rights and other assets, and from the municipal estate tax with respect to their immovable property located in Madeira and directly used to carry out one of the eligible activities.

Additional incentives are granted in favour of third parties which conclude transactions with ZFM companies. In particular, an exemption from withholding tax applies in respect of: (i) interest paid by ZFM companies to non-residents, provided the underlying loan is used to finance investments or activities taking place within the ZFM; and (ii) royalties paid by ZFM companies in exchange for the use of intangible rights provided they are exploited in activities carried out in the ZFM.

As to the indirect tax incentives, there is an exemption from customs duties on goods and raw materials processed in the ZFM, with exclusion of agricultural products. Furthermore, VAT rates are lower than those applicable in mainland Portugal.

In order to benefit from the ZFM regime, eligible companies must file an application with the local agency (Sociedade de Desenvolvimiento da Madeira: 'SDM') in charge of issuing the required authorization. The SDM's final decision is mainly based on the potential economic development and employment growth likely to be brought about by the project submitted by the applicant company. 2011.

The ZFM regime is due to expire on 31 December

\section{J. Spain: the Canary Islands tax regime ${ }^{92}$}

Another special tax zone was established in the archipelago of the Canary Islands, which is provided with a certain degree of regional autonomy by the Spanish Constitution..$^{93}$ In order to favour the devel- opment of the local economy, the Canary Islands Special Area (i.e. Zona Especial Canaria, hereinafter: ZEC) was established in 1994 with a view to promoting the economic and social development of the archipelago. ${ }^{94}$ The ZEC tax regime features a number of tax incentives in favour of certain local companies operating mainly in an international context with non-resident parties.

Eligible entities may be a local company or a permanent establishment of a resident or a nonresident company having separate bookkeeping. They must have their headquarters, place of effective management, and main office within the territorial limits of the Canary Islands, and at least one director must be resident for tax purposes in the archipelago.

As to the eligible activities, in principle any commercial, industrial, or service activity qualifies for the ZEC regime unless explicitly excluded by the ZEC legislation. Also financial activities may be carried out by ZEC companies, including banking, financing and leasing activities, insurance and reinsurance activities, and shipping activities.

In order to qualify for the tax incentives of the ZEC regime, eligible companies are required to carry out any of the above activities with parties non-resident in Spain, with other ZEC companies, and only in very limited cases with individuals and companies resident in Spain.

The tax incentives available to ZEC companies concern both direct and indirect taxation.

A reduced corporate tax rate of 1 per cent applies to ZEC companies' net income derived from one of the eligible activities, instead of the standard corporate tax rate of 35 per cent applicable in mainland Spain. 95 Furthermore, a (limited) exemption from withholding tax on dividends paid by ZEC companies is granted to non-resident recipients. Capital gains realized on the disposition of shares of ZEC companies are exempt from capital gains tax in the hands of non-resident shareholders.

The main indirect tax incentive is the exemption from the Canary Islands General Indirect Tax (i.e. the local VAT) with respect to supplies of goods and services effected by ZEC companies to non-resident companies or to other ZEC companies.

In addition, there are exemptions from the 1 per cent capital duty levied on most transactions, and from the transfer tax and stamp duties with respect to a number of transactions otherwise subject to these taxes.

The application of the ZEC regime is subject to the

\section{Notes}

92 The following bibliography was consulted for the Canary Islands regime: T. Rosembuj, 'Fiscal Opportunities in the Canary Islands', Intertax, 1996/10, p. 396; A. de Juan y Ledesma, 'Canary Islands and Madeira Free Zone Regimes: Some Issues and Prospects', European Taxation 1997/5, p. 173.

93 The relevant provisions are those contained in Title VIII of the Spanish Constitution of 6 December 1978, Arts. 137 through 158.

94 The ZEC legislation was introduced by Law No. 19/1994 of 6 July 1994, which amended the previous tax benefits introduced with Law No. 20/1991 of 7 June 1991. The ZEC regime was then amended by Royal Decree-Law 3/1996 of 26 January 1996.

95 The imposition of a 1 per cent tax rate rather than a total exemption on corporate profits of ZEC entities has the function to subject them in principle to Spanish corporate taxation, even though it entails an insignificant tax burden. The idea behind this lies in the fact that certain countries grant a participation exemption in respect of dividends distributed by foreign companies to resident companies provided the former are not exempt from corporate taxation in the foreign country, regardless of the tax rate actually imposed on their profits. Consequently, profits distributed by ZEC entities qualify for the participation exemption under the tax rules of these countries. 
approval by the ZEC Consortium, which is the body in charge of receiving the applications and issuing the required authorization. The latter depends upon the fulfilment of the legal conditions and upon the impact of the investment on the economic development of the archipelago.

The ZEC regime is due to expire on 31 December 2024, with the possibility of an extension of its validity.

\section{K. Evaluation}

From the above survey of the special tax regimes implemented in certain EU and OECD Member countries it may be implied that the issue of harmful tax competition is significant and needs to be tackled in order to curb the described undesirable economic distortions. In fact, in the light of the theoretical principles and of the definitions of harmful tax competition previously discussed it may be noted that there is a tendency to introduce special tax incentives meant to attract foreign investments or to re-attract economic activities previously shifted away due to special incentives granted by other (neighbouring) countries.

Examples shown in this brief survey included:

- the Belgian coordination centre regime and its competing regimes enacted by Ireland ('IFSC') and the Netherlands ('CFM');

- the competing administrative practices adopted in the Netherlands and France providing for a favourable tax treatment in favour of entities carrying on distribution activities;

- the competing holding regimes implemented by Luxembourg and Spain;

- the establishment of the ZEC in the Canary Islands, which was aimed at creating an attractive tax environment able to compete with the ZFM regime previously set up in the Madeira archipelago.

All of the above regimes may potentially constitute harmful tax competition according to the criteria laid down in the Code of Conduct and in the OECD Report. In particular, they are characterized by a (potentially) great impact on the undertakings' decisions on their investment location. Furthermore, all of them seem to deviate from the normal tax system in effect in the countries which have implemented them and are potentially able to erode the tax base of other countries.

Most of the described regimes are available mainly for multinational companies established and active in countries other than those in which the special regimes apply, and many tax incentives cover mostly transactions concluded with non-residents (i.e. ring-fencing). As to the Dutch CFM regime, its special feature is represented by the possibility to set up a tax-free financial risk reserve not available for resident taxpayers without international financial risks.

The Belgian coordination centre regime and the Dutch and the French regime on distribution centres may also fall foul of the criterion of the calculation of the taxable base according to principles other than the OECD ones. The cost-plus method used for coordination and distribution centres is a notional method to compute a company's taxable profits and apparently tend to turn out advantageous for BCCs, Dutch or French distribution centres taxwise. In fact, their amount of taxable income tends to be limited, especially due to the exclusion from their taxable base of significant items of operating expenses and to the low percentage applicable on such expenses. For instance, under these systems personnel and financial expenses of such entities are excluded from the calculation of their notional tax base. ${ }^{96}$ The legal certainty provided with respect to transfer-pricing matters also constitutes a considerable advantage. ${ }^{97}$

These special regimes are interesting also because they apply on the basis of favourable administrative practices laid down in resolutions adopted by these countries' tax authorities rather than on the basis of (special) laws passed by their central legislative bodies.

The Portuguese and Spanish special tax zones constitute a different example of possible harmful tax competition. They seem to be caught by the criterion of the absence or significant reduction of the tax burden imposed on eligible (non-resident) entities or transactions (concluded with non-residents).

However, other factors should probably be taken into account in the assessment of these two regimes. First, they have not been adopted by a central institution, but by local authorities endowed with a high degree of autonomous power under these countries' constitutions. Secondly, the underlying reason for the creation of special tax-free areas meant to attract multinational companies is to favour economic development and boost employment in these regions, which may be considered desirable due to their underdevelopment and underemployment, especially as compared to the standard level of development of most EU and/or OECD countries. Therefore, the pursuance of such goals of domestic policy may have these regimes not characterized as 'harmful' because the potential erosion of other countries' tax base is a mere 'side' effect subordinated on the achievement of these desirable goals. ${ }^{98}$

\section{Notes}

96 In particular, it is interesting to notice that the OECD Report targets those provisions 'applying a margin to certain expenses .... while at the same time excluding a portion of those expenses or of that revenue when calculating the margin' (p. 31).

97 Also with respect to transfer-pricing matters, the OECD Report is more specific than the Code of Conduct and indicates a specific category of harmful practices: see pp. 31-32 of the Report.

98 Once again, it is likely that there is an overlap between the rules of the Code of Conduct and the EU law rules on fiscal state aid contained in Art. 92 of the EC Treaty and it is uncertain what will happen with respect to such regimes. 
The described tax regimes are not the only special regimes currently taken into effect in EU and OECD Member countries. A number of additional instances of possibly harmful tax regimes implemented by various Member States in different sectors may also be pointed at: for example, there are special tax rules dealing with holding companies (Netherlands, Luxembourg, France), service centres (Belgium), distribution centres (Belgium), expatriate employees (Netherlands, Belgium, France), shipping activities (Netherlands, Luxembourg, France), and financial operations concerning Eastern Europe (Italy).

One may wonder whether it is possible at all to tackle harmful tax competition. The adoption of the Code of Conduct and the Report seems a good start and provides tools to bring further this process. In order to understand how this may be done, it is now necessary to analyze the remedies provided for by the two documents.

\section{Code of Conduct and Report: remedies to counter harmful tax competition}

\section{A. A glance to the future in the EU context: the 'Code of Conduct Group' and its difficult task}

The Code of Conduct contains two fundamental principles dealing with harmful tax measures: standstill and rollback. According to the former, Member States politically commit themselves to refraining from introducing new tax measures which appear to be 'harmful' under the criteria contained in the Code. ${ }^{99}$ The latter principle entails a commitment of the Member States to carry out an assessment of their existing tax measures that may fall under the scope of the Code and to dismantle them in pursuance of the Code provisions. ${ }^{100}$

The procedure and the timing to fulfil the above tasks are also specified in the Code. A group of representatives of the Member States as well as of the European Commission referred to as the 'Code of Conduct Group' (hereinafter: Group) has been established with a view to 'assess the tax measures that may fall within the scope of the Code and oversee the provision of information on those measures'. ${ }^{101}$

The Group must report to the Council and its main tasks are the completion of the process of repealing the harmful tax measures existing in the Member States (rollback) and the assessment of the compatibility of new tax measures planned to be introduced by them with the principles of the Code (standstill).

For this purpose, Member States commit themselves spontaneously to submit a list of the tax measures potentially harmful under the scope of the Code 'according to the principles of transparency and openness'. ${ }^{102}$ In addition, they are to provide any piece of information relating to their internal tax measures already in effect upon request of other Member States in case of their failure to include them in such list despite their harmful character according to the Code. ${ }^{103}$

As to the timing of this procedure, the minutes clarify that Member States set out a period of two years for the rollback (i.e. up to the end of year 2000), which may be extended up to five years (i.e. end of 2003) in particular circumstances upon approval by the Council. ${ }^{104}$

The necessary framework has thus been created to take action against harmful tax measures implemented by the Member States of the European Union. The question though arises: will it work?

The main concern relating to the Code of Conduct is about its legal nature: it is a mere 'resolution' which does not have legal force towards the Member States but simply ratifies a non-binding political commitment of the latter to abide by its terms. One may object that it constitutes a written commitment agreed upon by all Member States and that it is unlikely that they can afford to undergo the political repercussions at both European and domestic level deriving from ignoring its existence and not complying with it.

However, this is true only to a certain extent if one looks at what may happen in the future. A first hypothetical situation in which a Member State may plead not to be bound by the Code might be in case of a change of its parliamentary majority due to new elections. The Code has been adopted by representatives of the Member States' governments supported by a certain political party at domestic level at the time of its approval. Where during the five-year period of implementation of the rollback rule a different political party would obtain the parliamentary majority and form part of a new government in that Member State, it might well claim that it is no longer politically bound by the Code because the latter does not reflect the same political ideas.

Furthermore, even if this were not the case and the new government would actively cooperate in the attempt

\section{Notes}

99 Code of Conduct, Para. C.

100 Ibid., Para. D.

101 The group has been established by the ECOFIN Council of 9 March 1998 according to Par. $\mathrm{H}$ of the Code of Conduct. The detailed procedural rules relating to its internal functioning are contained in the ECOFIN Council Communique No. 2072 of 9 March 1998, referred to in the text.

102 See the Code of Conduct, Para. E. Indeed, a list of potentially harmful tax measures implemented by the various Member States has been submitted to the Code of Conduct Group on 17 July. However, it has not been released and strict confidentiality has been observed by the European institutions due to its extremely sensitive political meaning and implications.

103 Code of Conduct, Paras. E and F.

104 An exception is contained with regard to the Irish IFSC regime, which is authorized to remain in effect till 2005 with the deadline to grant the approval of new projects benefiting from the regime set for the year 2000 . 
to tackle harmful tax measures within the framework of the Group, a similar problem might arise at domestic level. The Group will review the harmful measures existing in each Member State and then will address to them a non-binding act (directly or through the Council) recommending repealing such measures. However, in order for the actual repeal to take place, there must be a decision voted by the Parliament of the various Member States concerned. It may well happen that the act issued by the Group would not be ratified at this stage because the political majority of some Member States is different from the one ruling at the time of the Code's approval.

Another likely situation of conflict with respect to the successful application of the Code of Conduct may arise in the practical application and interpretation of the criteria laid down to identify harmful tax measures. For instance, a Member State may not agree on the meaning of a certain word or criterion and thus may not be willing to dismantle an internal tax measure that, in its opinion, falls outside the scope of the Code.

A practical example may be given by the Dutch CFM regime, which was in fact not perceived by the Dutch government as falling under the scope of the Code of Conduct at the time of its implementation. ${ }^{105}$ On this point, it has already been stressed that this system may represent a deviation from the benchmark Dutch tax system, because the advantages of forming the FRR are available exclusively to multinational companies engaged in financing activities in addition to the possible reserves meant to cover for risks under the normal system of 'sound business practice'.

Another example may be constituted by the described regimes implemented by Belgium, the Netherlands and France relying on notional methods of taxation. Under these regimes, the profits of eligible entities are in principle subject to the normal system of taxation. The nominal way of calculating the tax base according to the cost-plus method is merely a 'safe harbour' contained in the transfer-pricing legislation in order to double-check that their taxable profits have been computed at a reasonable level in compliance and consistently with the standard method based on a company's financial statements. Consequently, the countries concerned may not see this as any 'deviation' from their normal taxation system.

What may happen in these cases is easily imaginable. The process meant to tackle harmful tax competition may be jeopardized due to retaliation of the other Member States, or other similar practices of international public law.

Indeed, a legal hook to solve this kind of controversy does exist in the EC Treaty: it is Art. 101.

This provision reads:

'Where the Commission finds that a difference between the provisions laid down by law, regulation or administrative action in Member States is distorting the conditions of competition in the common market and that the resultant distortion needs to be eliminated, it shall consult the Member States concerned.

If such consultation does not result in an agreement eliminating the distortion in question, the Council shall, on a proposal from the Commission, acting by a qualified majority, issue the necessary directives. The Commission and the Council may take any other appropriate measures provided for in this Treaty' (emphasis added).

Therefore, in the above-mentioned situations the Commission may undertake the consultation procedure provided for by this article in order to eliminate the distortion caused by a harmful tax measure which the Member State concerned would not be willing to dismantle. ${ }^{106}$ If such a consultation were not successful and that state would not be able to reach an agreement on repealing or amending its internal tax measure in a way that would not be harmful (and that would comply with the Code of Conduct), the Commission may submit a proposal for a directive to be approved by the Council according to the qualified majority rule. In that case, an unwilling Member State may be voted out and its decision not to comply with the Code overruled by the other Member States.

As a consequence, there would be a big difference as compared with the resolution containing the Code of Conduct, because such a directive would be binding towards the addressee Member States as to the results to be achieved (i.e. repeal of their harmful tax measure), leaving it up to them as to the legal act to be enacted domestically for this purpose. ${ }^{107}$

To date, Art. 101 has never been used by the EU institutions, the main reason being the qualified majority rule. In direct taxation matters, the unanimity rule set forth by Arts. 100 (and 100A) of the EC Treaty is strictly followed due to the will of the Member States

\section{Notes}

105 See D. Weber, 'Position of the Dutch State Secretary of Finance Concerning the Code of Conduct and the Dutch Financing Companies', EC Tax Review 1998/2, p. 65. In particular, on 23 December 1997 the Dutch State Secretary of Finance pointed out that the CFM regime appeared to be legal at the time of its implementation, because during the ECOFIN Council of 1 December 1997 it was not explicitly mentioned. Indeed, the State Secretary also added that the practical judgment on the harmful nature of regimes like the CFM is in the hands of the Code of Conduct Group, and that the government was ready to abolish or amend its regimes according to the decisions of the Group when necessary.

106 On the point, see the interesting comment of Wattel, n. 66 above, p. 20. The author maintains that the consultation requirement would already be satisfied by the meetings of the Taxation Policy Group that led to the implementation of the Code of Conduct, because it was made up of representatives of the Ministries for Finance of the Member States and the Commission. Hence, the Commission may skip this step and issue directly a Proposed Directive to dismantle the harmful tax measure to be approved by the Council under the qualified majority rule.

107 This is explicitly stated by Art. 189 of the EC Treaty, which deals with the Community legal acts. See, for a thorough explanation of the use and case law relating to this instrument in the area of direct taxation in the practice of EU law, B. J. M. Terra \& P. J. Wattel, European Tax Law (Kluwer, Deventer - Boston), p. 40. 
to keep as much sovereignty as possible. ${ }^{108}$ For this reason, it is unlikely that in case a consensus cannot be reached on a certain tax measure within the Group this article will be used. In effect, the resort to this remedy might prove to cause consequences even more dangerous than the failure to enforce the Code in the EU context, because the subtle political equilibrium in the sensitive area of direct taxation may turn out to be irreparably harmed, which might lead to the opposite result.

\section{B. The OECD recommendations and the creation of a 'forum on harmful tax practices'}

The OECD Report sets out several remedies considered to be effective in countering harmful tax practices in Chapter 3. They are contained in a number of recommendations and guidelines addressed to the Member countries, which are non-legally binding acts. There is a total of 19 recommendations broken down into three categories dealing with: ${ }^{109}$

(i) domestic laws of the Member countries;

(ii) tax treaties;

(iii) international cooperation.

The first group regards exclusively internal legislation to be adopted by the Member countries and includes: introduction of controlled foreign corporations (CFC) and foreign investment funds (FIF) rules; restriction on the application of the participation exemption and similar mechanisms to relieve international economic double taxation arising with respect to intercorporate dividend distributions; foreign income information reporting rules; transparency and objectiveness of the conditions for the issuance of advance rulings by a country's tax administration; consistent application of transfer-pricing legislation; access to banking information.

The recommendations of the second category state that tax treaties should: contain adequate provisions on exchange of information, which in turn must be used more efficiently and effectively; contain strict exclusion provisions and limitation of benefits rules; contain a comprehensive commentary clearly explaining the contracting states' internal anti-avoidance doctrines and rules applicable to treaty provisions; be terminated where concluded with tax havens. Furthermore, the undertaking of coordinated or joint enforcement procedures as well as the assistance in the recovery of tax claims is encouraged by the Report.

The third category of recommendations is meant to enhance international cooperation in order to counter harmful tax practices and is perhaps the most interesting attempt of the OECD to achieve this goal. In particular, Recommendation No. 15 constitutes the pillar of this category because it provides for the creation and establishment of a 'Forum on Harmful Tax Practices' (hereinafter: Forum), composed of representatives of the Member countries and whose main task is the actual implementation of the guidelines for dealing with harmful tax practices. ${ }^{110}$ The Forum is a subsidiary body of the organization's Committee on Fiscal Affairs and reports to the latter. The effectiveness of the Forum is reviewed after five years from its establishment and every three years thereafter.

The Forum should supervise on the implementation by the Member countries of the clauses of standstill and rollback contained in the guidelines annexed to Recommendation No. 15. In particular, the guidelines set forth that countries must refrain from adopting new harmful tax measures within the meaning of the Report or from broadening the scope of already existing ones in their legislation or administrative practices (standstill); and that they must review their existing harmful tax practices implemented as domestic tax law or administrative practices and repeal them (rollback).

A list of such measures must be drawn up by the end of the year 2000, and their abolition must be actually completed by the end of the year 2003. Extension is possible up to the end of 2005 in case taxpayers are benefiting from a certain special regime on 31 December 2000. ${ }^{111}$

In addition, several other tasks are assigned to the Forum and listed in Recommendations No. 16 through 19.112 In particular, the Forum will have to: (a) issue a list of 'tax havens' within the meaning of the Report by the end of the year 2000; (b) engage in dialogue with non-member countries (namely, with tax havens); (c) undertake and develop the study and discussion on other topics relating to harmful tax competition, such as domestic legislation that denies deductions for payments made to tax havens or that imposes withholding taxes on such payments, domestic and treaty rules on the definition of residence for tax purposes, transfer-pricing legislation and guidelines, thin capitalization rules, and domestic rules on the taxation of innovative financial instruments.

\section{Final remarks on the EU and OECD approaches towards harmful tax practices: parallel attempts, different results?}

After having analyzed the content of the EU Code of Conduct and the OECD Report, a final thought must be devoted to their likelihood actually to curb harmful tax competition.

It is interesting to notice at first the relationship

Notes

108 On this point, see, for instance, L. Hinnekens, 'Ruding Revisited?', EC Tax Review 1996/2, p. 91.

109 The 19 recommendations are contained in the OECD Report, pp. 40 et seq.

110 OECD Report, pp. 52 et seq.

111 Ibid., p. 56.

112 Ibid., pp. 57-61. 
between the two documents as clarified in the OECD Report: ${ }^{113}$ 'The review procedure reflects the different institutional frameworks within which each Organization operates. In addition, as noted above, the EU Code is part of a Package of measures whereas the OECD Guidelines are accompanied by 19 detailed Recommendations relating to specific issues of harmful tax competition.'

As to the possibility of the two documents to interact and of the respective review processes to be coordinated, the OECD Report specifies:114 'The Committee considers that each Organization is responsible independently for the interpretation and application of its respective instruments' (emphasis added). Thus, there seems to be no room for a joint effort by the EU and the OECD. This is due chiefly to the different political framework and legal nature of the two organizations as well as the different number and integration of the Member countries within their ambit.

With respect to the evaluation on the effectiveness of the two documents under review in countering harmful tax competition, it would seem that the OECD Report is at a disadvantage as compared with the EU Code of Conduct. The main reasons are that Luxembourg and Switzerland have not endorsed the OECD Report and there is a lack of legal remedies whatsoever in case of failure of its Member countries to comply with it. Conversely, the Code of Conduct seems to have greater chances to succeed due to its more comprehensive scope, to the very high degree of integration amongst the Member States of the EU, and to the legal (and political) remedies available under EU law.

Even within the EU, though, it is still uncertain whether the political commitment enshrined in the Code will work. In any case, it is remarkable that Member States have unanimously agreed on the fact that there are special tax regimes to be considered 'harmful' for the internal market and have acknowledged the need to dismantle them in order to preserve a balanced tax base and to prevent economic distortions. This would have been unthinkable up to a few years ago. Illustrative is the negative reaction of the Member States on the part of the Report of the Ruding Committee, which back in 1992 stressed the need to counter special tax regimes in effect within the then EC due to their distortive effects on the internal market. ${ }^{115}$

Time seems now ripe to tackle harmful tax competition at least within the EU framework: there is a certain political willingness of Member States to cooperate with each other. In this regard, it is desirable that also the Proposed Directive on taxation of interest from savings is adopted. No less important seems the approval of the Proposed Directive on taxation of intercompany payments of interest and royalties. In fact, it contains a special provision which excludes from the Directive benefits recipients that: (i) are subject to a corporate tax rate lower than the normally applicable rate for interest and royalties received; or (ii) enjoy a reduction in the tax base which would not be normally available to other companies. ${ }^{116}$ This would imply that some of the entities enjoying a preferential tax treatment (i.e. Belgian coordination centres, IFSC companies, Dutch CFMs, Luxembourg soparfis, ZEC and ZFM entities) might not qualify as beneficial recipients and would clearly be a disincentive for multinational companies to use such devices.

\section{Conclusions}

The analysis of the present study on harmful tax competition has shown that the debate on this issue has just begun and that there are some doubts and problems still unresolved to date. The main ones are:

- Does 'harmful' tax competition really exist?

- If so, is there a solution to deal with it (and curb it)?

- If so, is this solution workable in practice?

The first doubt stems from two basic reasons: the lack of a definition of 'harmful' tax competition and the experience of certain federalist countries, which do not consider this an issue and leave it up to their states on how to design their own tax systems. ${ }^{117}$ However, the first reason is not decisive for a negative answer, because lack of a definition so far does not mean impossibility of finding a workable one in the future agreed upon at international level. As to the second reason, the situation of a federalist country and its states is profoundly different from that of the international community and its countries or of a supranational organization (like the EU) and its Member States. Hence, the fact that tax competition does not constitute a problem and is even considered desirable by a federalist country does not entail that it may not amount to an undesirable problem to be tackled in the framework of the international community.

Moving on to the second problem, in principle there are two solutions to deal with it at international level: (a) eliminate every form of tax competition altogether;

\footnotetext{
Notes

113 Ibid., p. 11.

114 Ibid.

115 See the Report of the Committee of Independent Experts on Company Taxation, released in 1992 by the Committee chaired by Mr. Onno Ruding. In particular, the Ruding Committee proposed the imposition of a minimum tax rate of 30 per cent on corporate profits throughout Europe and recommended a minimum harmonization of the rules on the computation of the taxable base by all Member States. However, the latter criticized the Committee's recommendations on the grounds of their national sovereignty in the area of direct taxation and of the subsidiarity principle, and consequently largely rejected its conclusions and recommendations.

116 This anti-avoidance rule is contained in Art. 7 of the Proposed Directive.

117 On this point, see for instance D. Kenyon \& J. Kincaid, n. 3 above, and D. Kenyon, n. 3 above.
} 
or (b) eliminate only 'harmful' tax competition whilst at the same time promoting 'desirable' tax competition. The first option would mean that all the countries in the world (or the EU Member States assuming a solution limited to the EU) would have to sit at the same table and draw up a common tax system to be mandated for all of them. Needless to say, this would be unfeasible as well as inefficient. Consequently, the solution under (b) should be adopted: the criteria laid down in both the Code of Conduct and the Report to identify 'harmful' tax practices as well as the standstill and rollback provisions would seem apt for this purpose, as long as they would be backed up and reinforced by a concise, objective and universally accepted definition of 'harmful' tax competition.

With regard to the last question, the only way of making this solution workable would be to have the mechanisms to tackle 'harmful' tax competition: (a) transposed in a legally binding act; and (b) made enforceable with administrative and/or judicial remedies to be managed by supranational impartial bodies.

While this appears unfeasible to happen at an international level (and in the framework of the OECD), the situation is different at the EU level. In fact, the provisions of the Code of Conduct may be adopted in the form of a Directive approved by the Council and then transposed into the legal system of the various Member States by way of their internal approval procedures. The result would be the enforceability of such a directive by both Commission and Member States, with the judicial control administered by the European Court of Justice. ${ }^{118}$

\section{Notes}

118 Alternatively, there may be an inclusion of the basic definition of tax competition and of the main provisions of the Code of Conduct in the EC Treaty. The corollary would be to confer the supervision powers in this area on the Commission in a way parallel to what happens in the area of (fiscal) state aid, and the judicial control on the European Court of Justice. 